Ankara Üniversitesi Türk Inkılâp Tarihi Ensitüsü Atatürk Yolu Dergisi

S 24, Kasim 1999-2003 s. 487-526

\title{
Yeni Gelişmelerin Işı̆̆ında Geçmişten Günümüze Musul Meselesi
}

\author{
Dr. Emine KISIKLI*
}

\section{$\ddot{O Z E T}$}

Musul 1055-1056 yıllarında Selçuklu egemenliğine geçmiş, bu tarihten itibaren Türkleşen Musul çeşitli Türk devlet ve beylik egemenliğinde kaldıktan sonra 1514 Çaldıran Seferi ile Osmanlı hakimiyetine girmiştir. Mondros Mütarekesi'nin ilan edilmiş olmasına rağmen, 1918'de Musul Ingilizler tarafından haksız yere işgal edilmiştir. Lozan'da İngilizler Musul'u Irak stnırlar içerisine dahil ettirmeye çalışmışlar, Türkiye ise Musul'u Misak-ı Milli sınırları içerisine almaya çalışmıştır. Ancak taraflar anlaşamadıkları için Musul Sorunu yüzïnden Lozan Antlaşması'nın imzalanması tehlikeye girmiştir. Lozan'da antlaşmanm imzalanabilmesi için Musul sorununun Lozan Görüșmeleri dışında, ikili görüş̧melerle çözümlenmesine karar verilmiştir. Íkili görï̈șmelerden de sonuç alınamaynca, sorunun çözümü Milletler Cemiyeti'ne havale edilmiștir. 1926'da imzalanan Ankara Antlaşması ile Musul Irak'a birakılmıs, Türkiye'ye ise Irak petrollerinden 25 yl sure ile \%10 pay verilmesi kabul edilmiştir. 1951 yılına kadar ödemeler daha düzenli olarak yapılmıştır. Yeni gelişmelerin ışı̆̆ında Türkiye Irak petrollerine karşı almast gereken 5.5 milyon sterlinin 3.5 milyonunu almıs, 2 milyon sterlin alacaklı durumda kalmuştır.

Anahtar Sözcükler: Musul Meselesi Inkıta Dönemi (kesinti)

\section{SUMMARY}

The Seljuk dominated Musul in 1055-1056. After these years, Musul was being Turkicized. With the 1514 Çaldiran War, Ottoman Empire started to dominate Musul. In 1918 Musul was occupied unjustly by England despite Mondros Armistice. In Lozan Negotiation's, English wanted to show Musul in Iraq's Boundary although Turkey wanted show Musul in Misak-ı Milli Boundary. Because of this reason, both side couldn't reach an agreement. Also approving the Lozan Agreement became more difficult. To solve Musul Issue, both sides agreed to discuss this matter after the Lozan Negotiations. But in negotiations between Turkey and England, both side couldn't find a solution to solve this problem. Because of this problem, the League of Nations worked for solving the Musul Issue. With the

*Dr. Emine Kısıklı, Başkent Üniversitesi, Atatürk İlkeleri ve İnkılâp Tarihi, Öğretim Görevlisi. 
Ankara Agreement, which was signed in 1926, Turkey left Musul to Iraq but gained 10\% share of Iraqi Petrol for 25 years. The payments was done properly between 1926-1951. Because of the new developments, Turkey had to take 5.5 million sterlin. But Turkey took only 3.5 million sterlin and Turkey is owed 2 million sterlin more.

Key Words:

\section{I. DÜNYA SAVAŞI ÖNCESİ MUSUL MESELESI}

Musul meselesi, petrole sahip olma, petrol alanları üzerinde söz sahibi olabilme meselesi olarak değerlendirilmelidir. 20. yüzyılın başlarında dünya politikasının şekillendirilmesi görevini üstlenen İngiltere, Musul'u Irak toprakları içerisine dahil ettirmeye çalışarak ve Irak'ın himayesini üstlenerek, bu önemli petrol bölgesi üzerinde söz sahibi olabilme gücünü elde etmeye çalışmıştır. Günümüzde ise, o dönemde İngiltere'nin yaptığı işi A.B.D. gerçekleştirme gayreti içerisindedir. Dünyada petrolün $\% 28$ 'ini A.B.D. \%20'sini ise Avrupa tüketmektedir. A.B.D.'nin hesaplarına göre, bu ülkenin petrol tüketimi önümüzdeki 25 yılda \% 33 artacaktır. Dünyada toplam 30 trilyon dolar değerinde petrol rezervi vardır. Bugün dünyada bilinen petrol stokunun \% 65'i başta Suudi Arabistan ve Irak olmak üzere Ortadoğu'dadır.Yani Ortadoğu'da toplam 24 trilyon dolar değerinde petrol vardır. Bu miktarda bir petrolü ve onun fiyatını denetleyecek, petrol fiyatlarını kendi arzu ettiği biçimde istikrarda tutacak güç, önümüzdeki yüzyılın patronu olacaktır. İşte günümüzde büyük devletlerin iştahını bu kadar kabartan Musul petrolleri, aynı düşünce ile Türkiye'nin elinden alınmıştır. İngilizler bu işi nasıl başarmışlar, bu Osmanlı mirasını nasıl Türklere bırakmamışlardır?

Musul ilk olarak 1055-1056 yıllarında Selçuklu Devleti'ne bağlanmıştır. Bu tarihten itibaren Türkleşen Musul, I. Dünya Savaşı sonuna kadar çeşitli Türk devlet ve beyliklerinin ${ }^{1}$ egemenliğinde kalmış, Türkler tarafından bir vatan toprağı olarak görülmüştür. Musul, Osmanlı hakimiyetine Yavuz Sultan Selim'in 1514 tarihli Çaldıran Seferi ile girmiş, Kanuni'nin 15341535 Bağdat seferi ile bu hakimiyet perçinlenmiştir.

Osmanlı hakimiyetinin son yüzyılında Musul vilayeti, $91.000 \mathrm{~km}^{2}$. arazi üzerinde 350.000 nüfusu barındırmaktadır. İdari taksimata göre Musul; Kerkük, Süleymaniye ve Musul sancaklarına ayrılmaktadır 1330/1914 Salnamesi'ne göre Musul sancağı; Musul, Akra, Dahul, İmadiye, Zakho, ve Sincar; Kerkük sancağı, Kerkük, Revanduz, Kuşnuk, Köş, Raniye, Selahiye,

\footnotetext{
${ }^{1}$ Osmanlı Devleti öncesinde bölgede Zengiler, Timurlular, Akkoyunlular ve Safeviler hüküm sürmüşlerdir.

${ }^{2}$ Semih Yalçın, "Misak-1 Milli ve Lozan Barış Konferansı Belgelerinde Musul Meselesi”, Atatürk Araştırma Merkezi, Misak-1 Milli ve Türk Dış Politikası'nda Musul, Kerkük ve Erbil Meselesi Sempozyumu, Ankara 1998, s.155.
} 
Erbil; Sülaymaniye ise; merkez ile birlikte Kalambriye, Şehr-izor, Muhammerah ve Bazyan kazalarını içine almaktadır. ${ }^{3}$

I. Dünya Savaşı öncesinde Musul, tarım, hayvancılık ve yöresel üretimi ile Avrupalı tüccarların bildiği bir bölgedir. XIII. yüzyılda seyyah Yakut, Musul'u dünyanın üç önemli şehrinden biri olarak gördüğünü kaydetmekte ve sahip olduğu zenginliklerle Musul'un canlı, gelişmiş bir ekonomiye sahip olduğunu belirtmektedir. ${ }^{4}$

XX. yüzyıl başlarında insan hayatının her alanına önemli bir stratejik madde olarak giren petrolün, en erken keşfedildiği yörelerden biri de, Musul yöresidir. Petrole büyük ilgi duyan II. Abdülhamit, daha 1890'ların başında İngiltere'de öğrenim görmüș İstanbul'lu bir Ermeni tüccarın oğlu olan Kalust Gülbenkyan'a Musul civarında petrol ile ilgili araştırmalar yapma görevini vermiştir. Hatıralarında bölgede İngilizlerin "arkeolojik çalışma" maskesi altında petrol aramaları yaptı̆̆ından bahseden II. Abdülhamit, bu çalışmalar sonucu İngilizlerin açtıkları petrol kuyularını kapattırdığından, İngilizlerin kendisine olan düşmanlığının arttığından bahsetmektedir. ${ }^{5}$ Gülbenkyan'ın Musul civarında araştırmalarını tamamlayarak, yörede petrol bulunduğu yolunda rapor vermesinden sonra, II. Abdülhamit 1888 ve 1898 'de yayınladığı iki özel fermanla burasını "Memalik-i Şahane"si ilan etmiş ve kendi şahsi arazisi haline getirmiştir. ${ }^{6}$ 1791(1798)-1878 yılları arasında Çarlık Rusyası'na karșı Osmanlı Devleti'ni ayakta tutmaya çalışan İngiltere'nin, 1877-1878 Osmanlı Rus Savaşı sırasında Osmanlı Devleti'nin iyice güçsüzleştiğini görerek, Osmanlı Devletini korumaktan vazgeçmesi ve yıkma politikasını uygulamaya koyması üzerine, Osmanlı Devleti 1888-1918 yılları arasında Almanya ile yakınlaşma içerisine girmiștir.? İște bu dönemde Almanlara, Irak'ta demiryolu imtiyazı ile birlikte petrol arama imtiyazı da verilmiştir. Bu arada İran'dan 1901 yılında petrol arama imtiyazı alan İngilizler, Irak'ta da bu imtiyaza sahip olabilmek için İstanbul'da Osmanlı yetkilileri ile görüşmeler başlatmışlardır. Bu durum Almanların itirazlarına yol açmış ve 1908 II. Meşrutiyet hareketine kadar devam etmiş, İttihat ve Terakki döneminde petrol pazarlıkları, artarak sürmüştür. Musul yöresinde petrolün varlığının keşfedilmesi, İngilizlerin bu yöreye büyük önem vermelerine yol açmıştır. Hele Irak'ta Almanların nüfuzunda inşa edilmeye çalışılan Bağdat Demiryolu'nun, İngilizlerin Hindistan'daki varlığını tehdit edebileceği kaygısı, İngilizlerin dikkatlerini büsbütün Irak üzerine çevirmiştir. Dolayısıyla İngiltere, I. Dünya Savaşı'na büyük ölçüde Alman

\footnotetext{
${ }^{3}$ İslâm Ansiklopedisi, C.VIII., s.744.

${ }^{4}$ Mim Kemal Öke, Musul- Kürdistan Sorunu (1918-1926), İstanbul 1995, İz Yay., s.15.

${ }^{5}$ II. Abdülhamit'in Hatıra Defteri, Sadeleştiren İ. Bozdağ, Kervan Yay., İstanbul, 1975, s.80.

${ }^{6}$ Kemal Melek, İngiliz Belgeleriyle Musul Sorunu 1890-1926, Üçdal Neşriyatı, İstanbul, 1983, s.12; Öke, a.g.e., s.41.

${ }^{7}$ Fahir Armaoğlu, 20. Yüzyıl Siyasi Tarihi 1914-1980, C.I., Türk.İş.Bank.Yay., Ankara, 1994, s.45-46.
} 
tehlikesine karşı Hindistan'ı korumak ve Irak petrollerine sahip olabilmek için girmiştir. İngilizlerin petrol kaynaklarını tamamen kendi kontrollerinde tutma arzuları, onların Irak ve Musul üzerindeki arzularını büsbütün kamçılamıştır. Çünkü İngiltere o yıllarda ihtiyacı olan petrolün büyük bölümünü A.B.D. ve Rusya'dan temin etmektedir. Güçlenen Alman donanmasına karşı, kendi donanmalarının petrol problemini bir an önce çözmek için gerekli girişimlerde bulunma kararı veren İngilizler, ilk iş olarak İngiliz Hükümeti'nin Ortadoğu'daki petrol imtiyazlarını elde etmek için girişimlerde bulunması ve İngiliz dış politikasının da buna göre ayarlanması görüşünü öne sürmüşlerdir. 1907 yılında hazırlanan bir raporda, etkin sulama teknikleriyle bölgenin dünyanın en önemli tahıl ambarlarından biri olabileceği ve bölgede bulunan petrolün işlenmesi halinde çok karlı bir yatırıma dönüşebileceği vurgulanmıştır. ${ }^{8} 1912$ yılından itibaren de İngiliz Bahriye Bakanlığı petrol konusunda Ortadoğu politikasında söz sahibi olmaya başlamıştır. İngiltere bu amaçla İran ve Osmanlı Devleti'nden petrol imtiyazı almak için girişimlerini sürdürürken, I. Dünya Savaşı patlak vermiştir. ${ }^{9}$ I. Dünya Savaşı öncesinde Üçlü İtilâf ve Üçlü İttifak bloklarına mensup devletler arasındaki gerginliğin tırmanmasında ve bu gerginliğin bir büyük dünya savaşına yol açmasında Musul yüzünden, Körfez'de İngiltere ve Almanya arasında yaşanan rekabetin payı büyüktür.

\section{I. DÜNYA SAVAŞI YILLARI MUSUL MESELESI}

I. Dünya Savaşı'nın çıkması ile birlikte bölgede Osmanlı Devleti adına yapılan petrol arama ve çıkartma faaliyetlerine ara verilmiştir. I. Dünya Savaşı ile İtilâf Devletleri'nin Musul üzerindeki siyasi emelleri, Irak Cephesi'nin açılmasına yol açmış, savaşla birlikte Hindistan'dan gönderilen İngiliz kuvvetleri, Basra'ya çıkarak, 29 Eylül 1915'de Bağdat'ın 160 km. güneyindeki Kut'ül Amara'ya ulaşmışlardır. Çanakkale'de yaşadıkları büyük başarısızlıktan sonra, Bağdat'ı ele geçirmelerinin İslâm dünyasında kendilerine büyük prestij kazandıracağını düşünen General Townshend komutasındaki İngilizler, Bağdat'a 40 km. uzaklıktaki Selmanpak'ta savaşa girişmişler, ancak yenilerek Kut'ül Amara'da mevzilenmişlerdir. Townshend ve 20.000'e yakın askeri, 7 Aralık 1915'den, 29 Nisan 1916'ya kadar Dicle nehri üzerindeki yarı dairemsi bir bölgede savunmaya geçmişlerdir. İngilizlerin bütün çabası, Osmanlı kuvvetlerince kuşatmaya alınan bu birlikleri kurtarmaya yönelik bir çabadır. Enver Paşa'nın amcasının oğlu Halil Bey (Kut) komutasındaki 18. Kolordu kuvvetleri de, bu bölgedeki İngilizlere karşı savaşmak üzere, Enver Paşa'nın emriyle Irak'a sevkedilmişlerdir.

Daha sonra bölgeye Alman Mareşal Kolmar von der Goltz tayin edilmiştir. Bağdat'1 kaybetmenin çok kötü sonuçlar doğurabileceğinin

\footnotetext{
${ }^{8}$ Öke, a.g.e.s. 40.

${ }^{9}$ Melek, a.g.e.,s.53.
} 
farkında olan Goltz Paşa, Irak'a büyük önem vermiş ve beş ay süren çatışmalar sonunda, Townshend'i teslim olmaya mecbur etmiş̧ir. Townsed ve ordusu esir olurken, Alman generaller komutasındaki Osmanlı ordusu, Süveyș Kanalı'na ikinci bir sefer başlatmış, ancak bu girişim sonuçsuz kalmıștır. İngilizler ise, daha etkili olacak bir ayaklanmayı, Hicaz'da başlatmıșlardır. Çanakkale'den çektikleri birliklerinin bir bölümünü de bu bölgeye nakleden İngilizler karşısında, Halil Bey ve Kazım Karabekir Paşa komutasındaki Osmanlı ordusu geri çekilmek zorunda kalmış, 24 Şubat 1917'de Kut'ül Amara, 11 Mart’ta da Bağdat düşmüştür. ${ }^{10}$

İngilizler, I. Dünya Savaşı yıllarında bir yandan Musul'u elde etme girişimlerini sürdürürlerken, bir yandan da Musul üzerindeki siyasi ve stratejik hedeflerini belirleyecek bir program ortaya koyma hazırlığına girişmişler ve 1915 'de Sir Mauric Bunsen'in başkanlığında "Asya Türkiyesi'ni İnceleme Komisyonu” adıyla bir komisyon oluşturmuşlardır. Komisyon, Musul'un İngilizler açısından çok önemli bir bölge olduğu, dolayısıyla Musul'un savaş sonrasında mutlak surette İngiliz nüfuz alanı içerisine alınması doğrultusunda bir rapor vermiştir.Ancak İngiltere Musul yöresine bu kadar önem vermesine rağmen, Osmanlı Devleti'ne ait Ortadoğu topraklarının paylaşımı konusunda, müttefikleriyle anlaşamamış ve SkyesPicot Antlaşması ile Mezopotamya İngiltere'ye verilirken, Musul Fransa'ya bırakılmıştır. Albay Sir Mark Skyes'a göre bu İngiltere adına ciddi bir fedakarlık olmasına rağmen, İngiltere'de derin bir infiale yol açmamıştır."

\section{MONDROS MÜTAREKESI'NIN UYGULANMASI SIRASINDA MUSUL'UN DURUMU}

Mondros Mütarekesi'nin imzalandığı sırada Musul'da 6. Ordu Kumandanı Ali İhsan (Sabis) Paşa bulunmaktadır. Ali İhsan Paşa, Mütareke'nin imzalanmasından birkaç gün önce Musul'un İngilizlerin eline geçmemesi için gayret sarfetmiş, fakat başarılı olamamıştır.Mütareke'nin yürürlüğe girdiği 31 Ekim 1918, Saat: 12'den itibaren, Ali İhsan Paşa'nın 6. Ordusu olduğu yerde durmuştur. Bu sırada 6. Ordu birlikleri, batıdan doğuya doğru Rakka, Miyadin, Telafer, Dibeke, Çemçema, Süleymaniye hattı üzerindedir. İngiliz kuvvetleri ise, El-Hazar, Gayyare, Altınköprü, Kerkük, Hanikin hattında bulunmaktadır. ${ }^{12}$ Yani 30 Ekim 1918 günü, Kerkük merkezi hariç, Musul ve Musul vilayetinin büyük bir bölümü Osmanlı Devleti'nin kontrolündedir.İngilizler ise, ateşkesle savaşın sona ermesine rağmen, süratli bir işgal hareketi ile, Musul'a hakim olma çabalarını sürdürmüşlerdir. 1 Kasım'da Hamamalil'e giren İngilizler, Musul'u işgal edeceklerini söyleyerek, Türk kuvvetlerinin Musul'un 5 km. kuzeyine çekilmesini istemişlerdir. Ali İhsan Paşa, İngilizlerin bu talebini Sadrazam'a

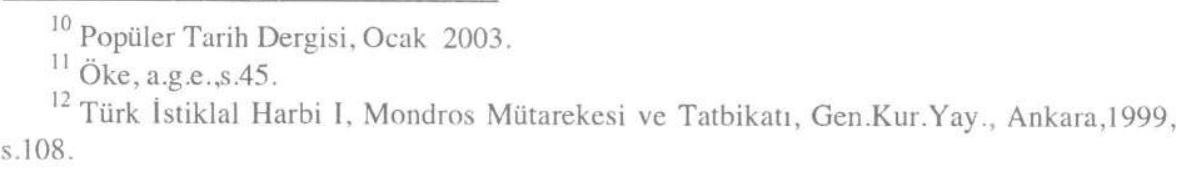


bildirmiş, 8 Kasım 1918 tarihli cevabî telgraf ile Sadrazam, Ali İhsan Paşa'ya Musul'un 15 Kasım günü boşaltılması talimatını vermiştir. Ali İhsan Paşa bu talimata uyarak, 10 Kasım günü Musul'u boşaltmış, ordu karargahı ile birlikte Nusaybin'e doğru çekilmiş, ${ }^{13}$ İngilizler de mütareke hükümlerine uymayarak, haksız bir biçimde Musul'u işgal etmişlerdir.

Bölünmez bir Türk yurdunun sınırlarını belirleyen ve son Osmanlı Meclis-i Mebusan'ının 28 Ocak 1920 tarihli gizli oturumunda kabul edilen Misak-1 Milli'nin birinci maddesi, Türkiye'nin güney sınırlarını çizmektedir. ${ }^{14}$ Buna göre mütareke hattı esas alındığında, Musul, Kerkük ve Süleymaniye'nin Anadolu'nun ayrılmaz bir parçası olduğu ortadadır. Çünkü Kerkük'ün de, mütarekeden sonra, Musul gibi, haksız bir biçimde İngilizlerin eline geçtiği kuvvetle muhtemeldir. ${ }^{15} \mathrm{Bu}$ durumu Mustafa Kemal Paşa da doğrulamakta, 28 Aralık 1920 tarihli konuşmasında, "Musul'un mütareke anında Türk Ordusu'nun hakimiyetinde olduğunu, işgalin Ingilizler tarafından, mütareke hükümlerine aykırı olarak gerçekleştirildiğini" ifade etmektedir. ${ }^{16}$

Musul'u haksız yere işgal eden İngilizler, bölgedeki aşiretleri kontrol altına alma konusunda ciddi sıkıntılar yaşamışlardır. Kerkük ve Süleymaniye halkı İngiliz işgaline sıcak bakmamış, müslüman kabileler ise, İngilizlere vergi verme konusunda direnç göstererek, sık sık sokak kavgalarına girişmişlerdir. Bölge halkının ekseriyeti Türkler tarafında yer almıştır.Musul halk1, Milli Mücadele hareketine destek vermiş, hatta bölgede bulunan Araplar dahi, İngilizlere karşı Mustafa Kemal Paşa ile işbirliğinden yana olmuşlardır. ${ }^{17}$

Musul halkının bu arzuları karşısında duyarsız kalmayan Mustafa Kemal Paşa, 1 Mayıs 1920 tarihinde B.M.M'nde yaptığı konuşmasında, "Hep kabul ettiğimiz esaslardan birisi ve belki birincisi olan sınır meselesi tesbit edilirken, milli hududumuz, İskenderun'un güneyinden geçip, do ğuya doğru uzanarak, Musul, Kerkük ve Süleymaniye'yi içine alır" ${ }^{\prime 8}$ demiştir. Bu kararlılık Mustafa Kemal Paşa tarafından, Lozan Konferansı'na kadar geçen dönemde de gösterilmiştir. İngilizlerin Ocak 1921'de, Erbil ve Revanduz

${ }^{13}$ Ali İhsan Sabis, Harp Hatıralarım, C.IV.,Ankara, 1951,s.7.

${ }^{14}$ Bu maddeye göre; "30 Ekim 1918 Mondros Mütarekesi imzalandığı tarihte, Osmanlı Devleti'nin özellikle Arap çoğunluğunun yaşadığı, halen düşman işgali altında bulunan bölgelerinin geleceği, bölge halkının hür iradesi doğrultusunda belirlenmelidir. Söz konusu mütareke çizgisi içinde din, soy ve amaç birliği bakımlarından biribirlerine bağlı olan, karşılıklı saygı ve sevgi duyguları besleyen, soy ve toplum ilişkileri ile çevrelerinin koşullarına saygılı Osmanlı-İ̀slam çoğunluğunun yerleşmiş bulunduğu kesimlerin tümü, hiçbir nedenle birbirinden ayrılmaz bir bütündür."

15 Nejat Kaymaz, "Misak-1 Milli Üzerinde Tartışmalar", VII.Türk Tarih Kongresi, Bildiriler, C.III.,T.T.K.Yay., Ankara,1983, s.1956.

${ }^{16}$ Atatürk'ün Söylev ve Demeçleri, C.II.,Türk İnk.Tar. Ens.Yay., Ankara, 1981, s.6.

${ }^{17}$ Yalçın, a.g.e., s.159.

${ }^{18}$ Atatürk'ün Söylev ve Demeçleri, C.I., s.74. 
arasındaki Türkleri destekleyen "Sürücü" aşiretine saldırmaları üzerine, Mustafa Kemal Paşa, Milli Müdafaa Vekâleti'ne bir telgraf çekerek, Revanduz bölgesine asker gönderilmesini istemiştir ${ }^{19}$. Bu görev Kaymakam ve Milis Yarbay Özdemir Bey'e verilmiş, Özdemir Bey başlangıçta kuvvetleriyle bölgede önemli başarılar elde etmiş, ancak daha sonra çekilmek zorunda kalmıştır. Özdemir Bey'in Revanduz'da elde ettiği başarı, Türk Genel Kurmay'ını Musul'u kurtarmak için askeri tedbirler alma düşüncesine itmiş, Genel Kurmay Başkanı Fevzi Paşa, El-Cezire Cephesi Kumandanlığı'ndan, 7 Eylül 1922'de Musul'a bir taarruz hazırlı̆̆ı yapılması talebinde bulunmuş ${ }^{20}$, ancak bu düşüncenin hayata geçirilebilmesi mümkün olamamıştır.

\section{LOZAN GÖRÜŞMELERİ SIRASINDA MUSUL MESELESİ}

\section{1- LOZAN GÖRÜŞMELERI'NDE TÜRK TEZİ}

Lozan Konferansı'nda üzerinde en çetin görüşmelerin yaşandığı konu, Musul konusudur. İsmet Paşa Lozan'da Türk tezini etnografik, hukuki, tarihi, coğrafi, ekonomik, askeri ve stratejik açılardan ele almış, bilimsel ve akılcı delillere dayandırmak suretiyle konuyu izah etmiştir. İsmet Paşa görüşmelerde, etnografik açıdan Musul vilayetinde yerleşik nüfusun son resmi istatistiklere göre $500.000^{21}$ civarında olduğunu söylemiş, Türk-Kürt ayırımı yapılmaksızın bölge halkının çoğunluğunun Türk olduğunu vurgulamış ve bölgenin Anadolu'dan ayrılamayacağını ifade etmiştir.

İsmet Paşa, hukuksal açıdan, ateşkes ilanından sonra işgal edilmiş olması nedeniyle, Musul'un işgalinin hem uluslararası hukuka, hem de Wilson Prensipleri'ne aykırı olduğunu vurgulamış, bölgede bir plebisit yapılmasını istemiş, ancak İngiliz Heyeti, bölge halkının cahil olduğu gerekçesiyle buna yanaşmamıştır.

Tarihsel olarak Musul'un XI. yüzyıldan beri Türk egemenliğinde olduğunu savunan İsmet Paşa, Musul'un coğrafi açıdan Anadolu'nun uzantısı olduğunu belirtmiş, ekonomik bakımdan da Musul'un Diyarbakır'a ve Akdeniz limanlarına bağlı olduğunu açıklamıştır.

Askeri ve stratejik açıdan da Musul'un Türkiye için hayati önem taşıdığını kaydeden İsmet Paşa, bu tezlerin yanı sıra İngiltere'nin Musul konusundaki çelişkilerini de ortaya koyarak, Musul konusundaki haklılığımızı göstermeye çalışmıştır. Örneğin, İngiltere'nin Ekim 1922 antlaşmasıyla Irak'ın toprak bütünlügüüü korumayı üstlendiği iddiasına karşı İsmet Paşa, İngiltere'nin Skyes-Picot Antlaşmasıyla Musul'u Fransızlara

\footnotetext{
${ }^{19}$ Türk İstiklal Harbi IV., Güney Cephesi, Gen.Kur.Yay., Ankara, 1966, s.267.

${ }^{20}$ Türk İstiklal Harbi, Güney Cephesi,s.282; Kamuran Gürün, Savaşan Dünya ve Türkiye, Ankara, 1986,s. 390-391.

${ }^{21}$ Seha L. Meray, Lozan Barış Konferansı, Tutanaklar, Belgeler, İstanbul, 1993, C.I., s.345.
} 
verirken, buranın Irak’tan ayrılabileceğini kabul etmiş olduğunu, ayrıca bu antlaşma Irak resmen Osmanlı Devleti'nin parçası iken yapılmış olduğu için, geçerli sayılamayacağını söylemiştir.

İsmet Paşa bazen 1lımlı bir tavır takınarak, Musul'un Türkiye'ye bırakılması halinde, dünyayı buradaki petrolden mahrum bırakmayacakları güvencesini vermiş, bazen de "Musul'u almadan Ankara'ya dönmem" diyerek, kararlı bir tutum takınmıştır. ${ }^{22}$

\subsection{LOZAN GÖRÜSMELERI'NDE İNGİLIZ TEZİ}

Etnik yapı bakımından Türk tarafının sunduğu istatistikleri kabul etmeyen İngiliz Heyeti, Türklerin bölge nüfusunun 1/12'sini oluşturduğunu öne sürerek, Kürtlerin 455.000, Türklerin 66.000, Hıristiyanların 62.000 olduğunu savunmuştur. ${ }^{23}$

İngiltere'nin konferans boyunca ve daha sonraki görüşmelerde en çok üzerinde durduğu nokta, Türklerle- Kürtlerin aynı soydan geldiklerine ilişkin Türk tezidir.Türklerle, Kürtlerin aynı soydan gelmedikleri ve farklı özellikler taşıdıkları görüşü, konferansta İngiliz tezinin temelini oluşturmuş ve Curzon "Müslüman Azınlık" kavramını ortaya atarak, Türk tarafını zayıflatmaya çalıșmıștır. Curzon bu iddianın yanı sıra, Türklerin Ermenilere ve diğer azınlıklara da kötü davrandığını ileri sürmüștür.

Curzon, Ekim 1922'de Irak'la yaptıkları antlaşmanın 8 maddesine göre, Irak'tan hiçbir şekilde toprak vermeme yükümlülüğü altına girdiklerini belirtmiş ve böylece Musul'un Türkiye'ye bırakılması halinde, sınırın Bağdat'a 60 mil kadar yaklaşacağını, bunun da Irak için ciddi bir tehlike oluşturacağını iddia etmiş, bu yüzden Türk tarafı konferans boyunca Türkiye'nin Misak-1 Milli sınırları dışındaki topraklar üzerinde herhangi bir talebi olmadığını ısrarla vurgulamıştır.

Türk yetkililerin Musul'un ateșkes ilanından sonra haksız yere işgal edildiği görüşüne karşı ise İngilizler, ateşkesin bölgede geç öğrenildiği, zaten mütarekenin 7. maddesinin de buna izin verdiği savunmasını yapmışlardır.

Türkiye petrole ihtiyacı olduğunu açıklarken Curzon, Musul'daki petrolün İngiliz politikasına hiçbir etkisi olmadığı görüşünü dile getirmiş, bu meselenin Musul'un geleceği ile ilgili bir mesele olmayıp, Türk-Irak sınırının belirlenmesi ile ilgili bir sorun olduğunu özellikle vurgulamışıı. ${ }^{24}$

\footnotetext{
${ }^{22}$ Baskın Oran, Türk Dış Politikası- Kurtuluş Savaşından Bugüne Olgular, Belgeler, Yorumlar- İstanbul, 2002, 6. Baskı, Illetişim Yay., C.I.,s.2.

${ }^{23}$ İngiliz tezine göre bu nüfusun 263.000'i Kürt, 146.000'i Türk, 43.000'i Arap, 18.000'i Yezidi, 13.000' $\mathrm{i}$ ise gayr-1 müslimlerden oluşmaktadır.

${ }^{24}$ Oran, a.g.e., C.I.,s. 262.
} 


\subsection{LOZAN'DA MUSUL VE PETROL ILE ILGÍLI} GÖRÜŞMELER

Lozan Konferansı'nın başlamasından kısa bir süre önce, Musul'un Türkiye'ye geri verileceği söylentileri ortaya atılmış, yerel İngiliz yönetiminin bu haberleri yalanlamasına rağmen, Irak Hükümeti'nde ve Irak bürokrasisinin üst kademelerinde görev yapan büyük toprak ağalarının huzuru kaçmış ve İngilizlere eskisi kadar yakın davranılmamaya başlanmıştır. Böyle bir ortamda başlayan Lozan Konferansı sırasında Musul ve petrol meselesi ilk defa, Amerikan delegesi Child ile Türk Heyeti'nden Celaleddin Arif Bey arasında 21 Kasım 1922 günü yapılan görüşmede ele alınmıştır. ${ }^{25}$ Musul ve petrol konusu daha sonra da, resmi toplantılar dışında İsmet Paşa ve arkadaşlarının 25 Kasım 1922 günü, diğer heyetlerle yaptıkları ikili temaslar sırasında gündeme gelmiştir. İsmet Paşa $26 \mathrm{Kasım} \mathrm{akşam}$ saatlerinde, İngiliz Heyeti Başkanı Lord Curzon ile de bir görüşme yapmıştır. İsmet Paşa 26 Kasım görüşmesinin içeriği hakkında, 27 Kasım tarihinde Ankara'ya gönderdiği telgrafta şu bilgileri vermiştir:

“Akşam Curzon ile Irak üzerinde özel olarak konuştuk. Musul vilayetini isteyeceğimizi söyledim. Fakat reddetti. Müttefiklerle tamamen mutabık olduğunu, Yunanlılara galip geldiğimizi, fakat Ingilizleri yenemediğimizi ifade etti. Aramızda ciddi tartışma geçti. Konuyu bir aralık petrole getirerek, bizim de petrole ihtiyacımız olduğunu söyledim. Bir petrol şirketi olduğunu, bunun dörtte birinin Fransizlara, dörtte birinin Ingilizlere, dörtte birinin Amerikalılara verildiğini, diğer dörtte birinin de diğerlerine ait olduğunu söyledi. Bu diğerleri Türkler olabilir dedim. Olabilir dedi. Bir de savaştan sonra paraya ihtiyacımız olacağını, devletlerin ortaklaşa borç verebileceklerini söyledi. Ben de bu işler hep konuşulabilir dedim. Fakat yarın konferansta ben Musul vilayetini isteyeceğim. Kendisi de kesinlikle reddetmek için bütün araçları ve bütün düzenlemelerini hazırladı̆̆ını söyledi. Karşlllk olarak dedim ki: Bu konuyu özel olarak aramızda müzakere edelim." 26

Bu görüşmeden iki gün sonra İsmet Paşa, İngiliz Dışişleri Müsteşarı Tyrell ile gizli bir görüşme yapmış,bu görüşmesini Ankara'ya aktardığ telgrafında, "İngiltere'nin Musul'u Türkiye'ye iade etmemekte kesin kararlı olduğunu, İngiliz temsilcilerinin petrole Türkiye'yi de iştirak ettireceklerini ve iktisadi yardım da yapacaklarını açıkladığını" belirtmiştir. ${ }^{27}$

Lozan Konferansı öncesinde Londra'da ortaya çıkan Irak'a yönelik politik belirsizlik, Lord Curzon'u bu sıralarda bir miktar esnek davranmaya

${ }^{25}$ Hikmet Uluğbay, İmparatorluktan Cumhuriyete Petropolitik, Ankara, 1995, Türkish Daily News Yay.,s.187.

${ }^{26}$ Bilâl N. Şimşir, Lozan Telgrafları I (1922-1923), Atatürk Kültür Dil ve Tarih Yüksek Kurumu Yay., TTK. Bas., Ankara, 1990, s.136.

${ }^{27}$ Şimşir, a.g.e., C.I, s.145. 
itmiştir. Ancak İngiliz diplomatları Musul petrolleri ve onun üzerinde oynanan oyunlar konusunda, Türk heyetine nazaran yaygın bir bilgi birikimine sahiptir. ${ }^{28}$ Dolayısıyla Musul'un İngiliz İmparatorluğu için önemini Hindistan Genel Valiliği döneminden beri çok iyi kavramıș bir diplomat olan Lord Curzon, Musul konusunda mutlak bir fedakarlıkta bulunulacaksa, bunun İngiltere'nin en az zararla atlatacağı bir fedakarlık olması kararlılı̆̆ındadır.

$\mathrm{Bu}$ arada İsmet Paşa Lozan resmi müzakereleri dışında yeri geldikçe Musul ve petrol konusunu İngilizlerle ve diğer devletlerin temsilcileri ile görüşmeye devam etmiştir. Bu çerçevede İsmet Paşa, 7 Aralık günü görüşmeye davet ettiği İngiliz Dışişleri Müsteşarına, Konferansta kesin tavır takınılacak ve karar verilecek aşamaya gelindiğini, görüşmelere Musul konusundan başlanılmasını önermiştir. Müsteşar ertesi gün harita üzerinde çalışmalara başlanılmasını önermiş ve bu öneri kabul edilmiştir. İsmet Paşa, bu toplantıyla ilgili olarak Ankara'ya gönderdiği telgrafında, konu üzerinde uzlaşmaya varılamadığını belirttikten sonra, İngiliz tarafının her zamanki gibi “anlaşırız" şeklinde güvence verdiğini kaydetmiştir. ${ }^{29}$

10 Aralık 1922 günü İsmet Paşa, Lord Curzon ile bir araya gelmiş ve Konferansa ilişkin çeşitli konuları görüşmüştür. Bu görüşmenin Musul bölümü ile ilgili olarak İsmet Paşa, Ankara'ya şu raporu iletmiştir:

"Musul konusunu açtığımda Lord Curzon kesinlikle reddetti ve bu konuda hükümetinden şimdiye kadar ki tutumunu destekleyen talimat aldığını belirtti. Bu açıklama üzerine uzun uzun tartıştık. Durumun kabul edilemeyeceğini ve tehlikesini vurguladım. Lord Curzon, bu durumun tehlikelerini kabul ettiğini ifade ettikten sonra, karşı görüşler ileri sürdü ve bu arada tehditlerde de bulundu". ${ }^{30}$

Lord Curzon'un başlangıçtaki tutumunu giderek katılaştırmasında, Londra'nın talimatının büyük payı vardır. Lord Curzon'un tutumu, Londra'da politika oluşturan tüm çevrelerden tepki almış, kendisine petrol ve Musul dolaylarındaki topraklarla ilgili olarak pazarlığa girmemesi

\footnotetext{
${ }^{28}$ Lozan görüşmelerine giden Türk Heyeti'nin Musul petrolleri ve onun üzerinde oynanan konusunda pek bilgi sahibi olmadığı, İsmet Paşanın Ankara'ya gönderdiği 2 Aralık 1922 tarihli telgraftan anlaşılmaktadır. 30 Kasım tarihli görüşmelerde Türk Petrol Şirketi'nin, Irak petrolleri üzerindeki hakkının nereden doğduğu uzmanlarımızca tartışmaya açılmış, İngilizler tarafından da geçmişi araştırılmış olmalı ki, İsmet Paşa bu bilgilerin doğruluğunu Ankara'nın doğrulaması ihtiyacını duymuştur. Başbakan Rauf Bey, İsmet Paşa'nın bu telgrafını 6/7 Aralık gecesi cevaplamış, Musul vilayeti dahilinde Almanlara petrol imtiyazı verildiğini, ayrıca Musul, Bağdat ve Basra vilayetleri dahilindeki kömür ve petrol madenlerinin17 Şevval 1324 (22 Kasım 1906) tarihli ferman uyarınca Hazine-i Hassa'ya ait olduğunu bildirmiştir. Şimşir, a.g.e., C.I, s.172, Belge No: 87.

${ }^{29}$ Şimşir, a.g.e., C.I, s.183, Belge No: 103 .

${ }^{30}$ Şimşir, a.g.e., C.I, s.197, Belge No:118.
} 
talimatı verilmiştir. ${ }^{31}$ Bu arada Lord Curzon, Musul'u neden Türklere geri vermeyeceklerini, gerekçeleri ile açıklayan bir raporu 14 Aralık günü Türk yetkililere iletmiştir .Lord Curzon bu muhtırada sunduğu gerekçelerin yanısıra $^{32}$, Milletler Cemiyeti'nin, mandaterliğini İngiltere'ye vermiş olduğu toprakları, bir başka ülkeye terk edemeyeceğini de özellikle vurgulamıştır.

Görüldüğü üzere Türk Heyeti başlangıçta Lozan Barış Konferansı'nın gündemine ilişkin konuları, konumuz olan Musul sorununu, resmi, özellikle de gayr-1 resmi toplantılarda görüşmeye ve bu sorunlara kendisini tatmin edecek çözümler aramaya devam etmiştir. Konferansın geniş gündemi, Türk ve İngiliz Heyetlerini ikili görüşmeler yapmaya da zorlamış, ancak Türk Heyeti fırsat buldukça Musul konusundaki taleplerini, İngiliz yetkililerine anlatmaya çalışmasına rağmen, İngiltere tavrını değiştirmediği gibi, giderek sertleştirmiştir.

Musul konusunun resmi toplantılarda çok fazla görüşülmemesi, diğer heyetlerde rahatsızlık yaratmış, bu durum onları Musul ve petrol meselesi hakkında Türk yetkililerle, doğrudan veya dolaylı görüşmeler yapmaya itmiştir. Bu ülkelerin başında A.B.D. gelmektedir. 17 Aralık günü İsmet Paşa'yı ziyaret eden A.B.D. Heyeti Başkanı, ülkesinin savunduğu "Açık Kapı" politikasını açıkladıktan sonra, bazı bölgelerde askıda kalmış olan politik sorunların, ekonomik ayrıcalıklar verilerek çözülmesine karşı olduklarını ifade ederek, İsmet Paşa'dan bu husustaki görüşünü sormuş, Paşa da bu şekilde verilmiş bir ayrıcalığın olmadığını söylemiştir. A.B.D. Heyeti Başkanı bu görüşmede Musul konusundan açıkça bahsetmemiş, ancak İsmet Paşa bu sorunun arkasında Türkiye'ye, Musul petrollerine ilişkin bir ayrıcalık verip, verilmediğinin öğrenilmesi arzusunun yattığını fark etmiş ve görüşmeyi Ankara'ya ileten telgrafında, bu endişesine yer vermiştir. ${ }^{33}$

Türk Heyeti, Lozan Konferansı sırasında bir yandan müttefik devletler heyetleri ile mücadele ederken, bir yandan da bu ülkelerin sahip oldukları

\footnotetext{
${ }^{31}$ Uluğbay, a.g.e.,s.193.

${ }^{32}$ Curzon, daha önce Musul ve havalisi hariç, Süleymaniye'nin kuzeyindeki dağlık
} bölgeyi Türkiye'ye bırakabileceklerini belirtmiştir. Ancak Londra'nın talimatından sonra Curzon, Musul konusunda taviz vermez bir tutum izlemeye başlamış, sözü edilen raporda şu gerekçeleri ileri sürmüştür:

a) Bu dağlık bölgeyi Türkiye'ye vermek, İngiltere'nin müzakeredeki durumunu zayıflatır ve Türkiye'yi Musul vilayetinin tamamını talep etmeye yöneltir.

b) Kürt nüfusun yoğun olduğu bu dağlık bölgeleri Türkiye'nin alması halinde, Türkler bu bölgenin hemen güneyindeki Türk nüfusun yoğun olduğu toprakları da almak isteyecektir.

c) Bu bölgelerin Türkiye'nin eline geçmesi, Irak'taki ulaşımın aksamasına ve Bağdat ile İran arasındaki ulaşımın da tehlikeye girmesine yol açacaktır.

d) Irak'ın idari yönetimi bakımından ek zorluklarla karşılaşılır ve dolayısıyla İngiltere'nin bölgede daha fazla asker bulundurmasını zorunlu kılar.

e) Musul ve çevresi zengin petrol yataklarına sahiptir.Bunların denetimini İngiltere'nin elinden çıkartmamak gerekir. Uluğbay, a.g.e., s.194.

${ }^{33}$ Şimşir, a.g.e., C.I, s.239, Belge No: 168 . 
teknoloji ile, Türk Heyeti'nin gizli haberleşmelerini çözmelerinin sağladığı müzakere dezavantajı ile karşı karşıya kalmıştır.

İngilizlerin Türk haberleşmelerini çözmesi, müzakerelerde bu ülkeye yönlendirici olma imkanı vermiştir. ${ }^{34}$

2 Aralık günü İsmet Paşa, Lord Curzon'a Musul konusundaki cevabi raporunu göndermiştir. Paşa raporda tüm gerekçelerini sıraladıktan sonra, Musul'un Türkiye'nin ayrılmaz bir parçası olduğunu bir kez daha vurgulamıştır. İsmet Paşa'nın cevabını alan Lord Curzon, bu gelişmeyi Londra'ya aktarırken, "Uzun bir hazırlıktan sonra Türkler Musul hakkında oniki sayfalık bir cevap verdiler. Noel Tatilimin tek uğraşı, bu raporu çürütme çalışması olacaktır" demiştir. ${ }^{35}$

İsmet Paşa 24 Aralık günü Ankara'ya gönderdiği telgrafında, Musul konusunun çok taraflı hale getirilmesinin, Türkiye'ye yönelik baskıları artıracağı ve dolayısıyla Türkiye'nin müzakere gücünü düşüreceği kaygılarını dile getirmiş, konunun İngiltere ile Türkiye arasında ikili görüşmeler yoluyla çözümünden yana olduğunu belirtmiștir. ${ }^{36}$

27 Aralık günü Lord Curzon'un Noel Tatili'nde hazırladığı Musul'a ilişkin İngiliz cevabı, Türk Heyeti'nin eline ulaşmıştır. İsmet Paşa, İngilizlerin cevabını nasıl karşıladığını şu cümlelerde ifade etmiş̧tir:

"Raporları şiddetli ve saldırgan bir dille yazılmış. Bizim delillerimizi çürütmeye çalışıyor, fakat başarılı olamıyorlar. Mektuplarında artık karşılıklı delil ileri sürmeye gerek yoktur, diyorlar. Galip olarak Irak't almışlar. Irak Kralı ile anlaşma yapmışlar. Kürdistan'a idari özerklik vermişler. Halbuki biz muhtıra ve mektubumuzda Kürdistan'a daha serbest bir idare vermek istediğimizi zannettirecek bir şey söylememişiz. Özetle Musul'u katiyen terk edemezlermiş". ${ }^{37}$

$\mathrm{Bu}$ ifadelerden de anlaşılacağı üzere Lozan barış görüşmeleri yılbaşı öncesinde çıkmaza girmiştir. Böyle bir ortamda İsmet Paşa, Musul konusunda içinde bulunulan durumu şöyle özetlemiştir:

“...Kesin karar günlerindeyiz. Oysa görüşlerimizde bir yakınlaşma yoktur. Musul konusunda kesin tavır takınmışlar...Konferans her an kesilebilir" ${ }^{38}$

Konferansın her an kesilme ihtimalinin olduğu bu günlerde, 29 Aralık 1922 günü II. Abdülhamit'in mirasçılarını temsil eden Untermyer, İsmet

\footnotetext{
${ }^{34}$ Uluğbay, a.g.e., C.I, s. 196.

${ }^{35}$ Şimşir, a.g.e., C.I, s.273, dipnot.

${ }^{36}$ Şimşir, a.g.e., C.I, s.275, Belge No:205

${ }^{37}$ Şimşir, a.g.e., C.I, s.288, Belge No:223.

${ }^{38}$ Şimşir, a.g.e., C.I, s.289-290, Belge No:223.
} 
Paşa'yı ziyaret etmiştir. Amerikalı işadamı, müvekkillerini temsilen Paşa'ya şu bilgileri vermiştir:

“Abdülhamit'in Makedonya'dan, Irak'a kadar Osmanlı topraklarının çeşitli bölgelerinde arazi ve mülkleri vardır. Bunlar 1909 yılında Hazine- $i$ Hassa'dan Maliye Nezareti Hazinesine devredilmiş ise de, mirasçıların başvurusu üzerine, Şer'i Mahkeme ve Şeyhülislam bu devir işleminin haksız olduğu kanaatine varmıştır.Sözü edilen bu mal varlı̆̆ının büyük bölümünün Türkiye sınırları dışında kalması yüzünden, hem mirasçılar hem de devlet bu mallar üzerindeki hakları açısından zarar görmüşür." ”39

Untermyer bu görüşme sırasında hem mirasçılarının haklarını korumayı amaçlamış, hem de Türk Hükümetine pay sağlamak gibi bir gaye gütmüş görülmektedir.İsmet Paşa bu görüşmenin yapıldığı gün Ankara'ya, bu Amerikalı işadamının açıklamalarını aktarmıştır.

İsmet Paşa görüldüğü üzere bu Amerikalı işadamını kabul edip görüşlerini Ankara'ya aktardığı gibi, O’nun teklifine sıcak da bakmıştır. ${ }^{40}$

$\mathrm{Bu}$ gelişmeler yaşanırken, yılbaşı tatilinin yaklaşmış olmasına rağmen, Lozan görüşmeleri resmi oturumlar ve ikili görüşmeler şeklinde devam etmiştir. İsmet Paşa 30 Aralık günü, Ankara’ya gönderdiği telgrafında, “Lord Curzon'un Musul konusundaki muhtırasına cevap verdiğini iletmiş ve her taraftan her türlü tehdit ve haberlerin yayılmakta olduğunu, Musul konusu çözümleninceye kadar, karşı tarafı çıkar birliğine yöneltebilecek oluşumlara izin vermemesini Ankara'ya önermiştir." ${ }^{41}$ Yine aynı güne ilişkin Ankara'ya yaptığı değerlendirmelerinde İsmet Paşa, “İngilizlerden henüz bir haber çıkmadığını, İngiltere'nin Musul konusunda ciddi bir karar verme noktasında olduğunu, Fransız. basınının güçlü bir biçimde Türkiye'yi tutar nitelikte yazılar yayınladığını, Ingiltere'nin bu nedenle Musul'daki emellerine ulaşabilmek için, Kapitülasyonlar konusunu ileri sürerek, Müttefik ülkeleri Türkiye aleyhinde birleştirme taktiği izlediğini ileri sürmüş̧ür. Ayrıca Lord Curzon'un 31 Aralık günü Paris'e giderek, Fransız. Başbakanı ile Almanya'nın savaş tazminatı konusunu görüşeceğini bildiren

\footnotetext{
${ }^{39}$ Şimşir, a.g.e., C.I, s.294, Belge No:227.

40 İsmet Paşa Ankara'ya gönderdiği telgrafında, bu kanaati uyandıracak şu bilgilere yer vermiştir: “... Bu grubun önerdiği çözüm yolu benimsenirse, Amerikan Hükümeti'nin Musul konusunda, Türkiye lehine ağırlığını koyacağına kesin gözüyle bakılamazsa da, her halde olasıdır.Grubun hükümete sağlayacağı faydalar vardır. Hükümet mirasçıların Şer'i Mahkeme tarafından kabul edilen haklarını onaylarsa, mirasçılar Türk uyruğunda olduklarından, söz konusu mal varlığı kendilerine dönmüş olacaktır. Amerika Grubu da hükümete hem gelir üzerinden bir yüzde ayıracak, hem de hisse senetlerinden önemli bir bölümünü verecektir.Bu durumda petrol bulunan araziden bir kısmı Türk egemenliğinden çıksa bile, bazı Türk uyrukluların yararlanması mümkün olacaktır.” Uluğbay, a.g.e.,s.198.

${ }^{41}$ Şimşir, a.g.e., C.I, s.299,Belge No:234.
} 
Issmet Paşa, bu görüşme sırasında Musul konusunun da bir karara bağlanabileceğini ümid ettiğini" iletmiştir. ${ }^{42}$

İsmet Paşa'nın bu iyi niyetli beklentisi çok geçmeden olumsuz bir havaya bürünmüş, Lord Curzon Fransa'ya hareket etmeden önce Musul konusunu bitirmek arzusuyla olsa gerek, Türk Heyeti'ne Musul konusundaki cevabını iletmiştir. İngilizlerin Musul konusundaki cevaplarını yumuşak bir dille kaleme aldıklarını ifade eden İsmet Paşa, "Artık tartışmayı gereksiz buluyorlar. Tarafların birbirlerini yanlış anladığını ifade ediyorlar. Ben daima Musul'un güney hududundan, onlar da Irak'ın kuzey hududundan bahsediyorlar.Paris'ten döner dönmez iki tarafın uzmanlarının sınırt belirleme çalışmaları yapmalarını öneriyorlar." ${ }^{43}$ demiștir. Bu arada Lord Curzon vakit geçirmeden Londra'dan bu konuda uzman gönderilmesini istemiştir.

Lozan'da durum bu şekilde iken, Başbakan Hüseyin Rauf Bey, 2 Ocak günü İsmet Paşa'ya daha önce kendisine ilettiği üç ayrı konuya ilişkin görüşlerini aktarmıştır. Başbakan ilk telgrafı ile Amerikalı işadamı Untermyer'in girişimi ile ilgili olarak İ̀met Paşa'ya şu talimatı vermiștir:" Abdülhamit'in mirası çerçevesindeki emlak ve arazilerden, milli sinırlar dışında kalanların mirasçılara ait olduğunu kabul etmek uygun görülmektedir. Ancak buna karşılık mirasçılar da, milli sınırlar içinde kalan söz konusu nitelikteki emlak ve arazilerin devlet hazinesine ait olduğunu kabul etmeli ve bu araziler üzerinde hak iddia etmeyeceklerini beyan etmelidirler. Musul milli sınırlar içinde olduğundan, petrol ayrıcalı ̆̆ konusunda şimdiden bir yükümlülük altına giremeyiz. Mirasçılar adına hareket eden şahsın, Musul'un Türkiye'ye iadesi için Amerika'nın destek vereceğine ilişkin açıklamaları, Lozan'daki Amerikan resmi heyeti tarafindan da doğrulanıyorsa, bu Ankara'ya bildirilmelidir." Untermyer'in ileri sürdüğ̈̈ Amerika'nın Musul'un Türkiye'ye iadesi konusunda destek vereceği açıklamasına rağmen, Türkiye görüldüğü üzere bu konuda henüz Amerika'dan somut bir adım görememiştir. Türkiye Musul'u kazanmak için, padişahın milli sınırlar dışındaki mal varlığını bile kabule hazırdır. Rauf Bey'in Lozan'daki İsmet Paşa'ya gönderdiği ikinci telgrafta ise, İstanbul'daki gayr-1 resmi Fransız çevrelerinin, Musul sorununun konferans dışında, İngilizlerle ikili görüşmeler yoluyla ele alınıp çözümlenmesi görüşünü savundukları aktarılmıştır. Üçüncü telgrafta ise Başbakan, Musul konusunda Fransız Büyükelçiliği'den alınan bilgileri İsmet Paşa'ya nakletmiştir. Fransızlar'a göre "Ingilizler Musul problemi nedeniyle Lozan Konferansı'nı başarısızlığa sürüklemekte, aynı zamanda konferansa katılan tüm devletlerin müzakere heyetlerini kendi yanlarına çekerek, Türkiye'yi uzlaşmaz göstermeye çalışmaktadırlar. Musul konusunun konferanstan ayrı olarak, Türkiye ile Ingiltere arasında çözümlenmesi doğrultusunda

\footnotetext{
${ }^{42}$ Şimşir, a.g.e., C.I, s.301,Belge No:238.

${ }^{43}$ Simşir, a.g.e., C.I, s.307-308,Belge No:247.
} 
Türkiye'nin yapacă̆ $\breve{\imath}$ öneri, bu İngiliz oyununu bozacaktır. Musul'un konferans dıșında tutulması kaydıyla barış antlaşmasının imzalanması halinde, Ingiltere Türklerin karşısında yalnız birakılacak, İngiliz kamиoyu Musul sorunu nedeniyle Türkiye ile savaşı asla göze alamayacaktır. Türkiye'nin yapacă̆ böyle bir önerinin İngilizler tarafindan reddi ise, diğer heyetlerin Türk tarafinı desteklemesine yol açacak ve Musul sorunu yüzünden konferansın başarısızlığa uğramasına göz yumulmayacaktır”. 44

Fransızlar bu tekliflerinde ne kadar samimidirler. Bu teklif gerçekten Türk Devleti'nin Lozan Konferansı'nda başarıya ulaşması amacıyla mı yapılmıştır? Yoksa, Fransızların bir oyunu mudur? Türkiye ikili görüşmelere zaten karşı değildir. Ancak doğal olarak Türk Hükümeti'nin bu konuda Fransızların samimiyetine güvenmesi de oldukça zordur.

Bu arada da Ankara'da önde gelen bazı siyasiler, Musul'un geleceğine yönelik net tavırlar ortaya koymaya başlamışlardır. Başbakan Hüseyin Rauf Bey, bu gelişmeleri İsmet Paşa'ya aktarmaktadır. Nitekim Rauf Bey 3 Ocak 1923 günkü telgrafında," Fevzi Çakmak Paşa'nın her ne şart altında olursa olsun, Musul'un Türk egemenliğine geçmesi görüşünde olduğunu" iletmiştir. ${ }^{45}$

İsmet Paşa aynı gün Ankara'ya gönderdiği telgrafında, "Lozan'da Musul'da isyan çıkacă̆ına dair söylentiler dolaştığııı" bildirmiştir. ${ }^{46}$

$\mathrm{Bu}$ arada İngiliz Heyeti, Musul vilayetinin sınırlarını görüşme talebinde bulunmuş ve iki tarafın uzmanları 3 Ocak akşamı bir araya gelmişlerdir. Bu toplantı sırasında İngilizler, o güne kadar sürdürdükleri tutumlarından vazgeçerek, Musul vilayetinde Arapların, Irak'1n bütünü göz önüne alındığında azınlıkta kaldıklarını, ancak askeri strateji açısından bu toprakların Irak'a gerekli olduğunu, bu sebeple iki devlet arasındaki sınırın, Musul vilayetinin kuzey hududu olması lazım geldiğini öne sürmüşlerdir. Ancak bu sınır belirleme görüşmelerinden de bir netice alınamayacaktır. Türk Heyeti o günlerde bazı İngiliz kaynaklarından, İngiltere'nin Musul konusunu konferans dışında iki ülkenin kendi aralarında konuşmasından yana olduğu duyumunu almıştır. ${ }^{47}$

3 Ocak 1923 günü Anglo- Amerikan adlı bir petrol şirketi yöneticileri İsmet Paşa'yı ziyaret etmiş, "Musul vilayetindeki petrol için, elli yıllık bir ayrıcalık karşılı̆̆ında Türkiye'ye \%12.5 'luk bir pay önermiştir. Şirket yöneticileri bu ayrıcalığın Musul'un Türkiye'ye iadesi şartına bağlı olmasını, kendilerinin Amerikan ve Fransız uyrukluları da eşit şartlarda ortak edeceklerini, toplayacaklarl sermaye ile Ingiliz. Hükümetini Musul'dan vazgeçmeye razı edebileceklerini, ayrıcalığın kendilerine verileceğine ilişkin

\footnotetext{
${ }_{44}^{44}$ Bu üç telgraf için bak., Şimşir, a.g.e., C.I, s.312, Belge No: $256,257,258$.

${ }^{45}$ Şimşir, a.g.e., C.I, s.317, Belge No:262.

${ }^{46}$ Şimşir, a.g.e., C.I, s.319-320, Belge No:265.

${ }^{47}$ Şimşir, a.g.e., C.I, s.328,Belge No:276.
} 
resmi bir yazı talep ettiklerini" bildirmişler, ancak kendilerine herhangi bir yazılı belge verilmemiştir. ${ }^{48}$ Türkiye Lozan'da, görüldüğü üzere Musul'un Türkiye'ye verilmesi konusunda tavizsiz, fakat Musul petrolleri konusunda paylaşımcı bir politika uygulamıştır. Nitekim bu yorumu doğrular nitelikte bir gelişme o günlerde Ankara'da yaşanmıştır. İstanbul'daki A.B.D. yetkililerinden Mr. Barney ile 5 Ocak günü görüşen Başbakan Rauf Bey, O'na 'Musul'un Türkiye'nin ayrılmaz bir parçası olduğunu, ancak petrol konusunda herkesle anlaşmaya ve ekonomik konularda açık kapı politikası izlemeye hazır olduklarını" bildirmiştir. ${ }^{49}$ Ancak petrol konusu İngiltere, Amerika ve Fransa'yı bir arada tutan bir yapıştırıcı durumunda olduğu ve her biri bu konuda aralarında çıkacak bir çekişmeden kimin galip çıkacağından emin olmadıkları için de, tek başına Türkiye'nin tezine destek verme eğiliminde görülmemektedirler. ${ }^{50}$

Musul konusundaki gerginliği aşmak isteyen İngiltere, Türkiye'ye petrolden pay vererek sorunu aşmaya karar verir. Bu amaçla İngiltere, Irak Hükümeti'nden gelebilecek bir itiraza karşı Bağdat üzerinde baskı uygulamaya başlar. Bu gelişme İsmet Paşa'yı pek memnun etmemiştir. Paşa, Lord Curzon'un Müsteşarı'ndan konuyu öğrendikten sonra, Ankara'ya gönderdiği telgrafında şu satırlara yer vermiştir: "Musul şehrini vermeden, petrolden bize hisse vermeyi öneriyorlar. Musul şehrini istediğimizi söyledim. Bizim için Musul bir vatan konusu, kendileri için ise petrol konusudur. Petrol konusunda kendilerini tatmin edecek şekilde birlikte çalışmaya hazır olduğumuzu söyledim. Musul'u veremeyeceklerini söylediler". 51

Musul konusunda İngilizlerden beklediği uzlaşmayı göremeyen İsmet Paşa, 6 Ocak sabahı Fransız Heyeti Başkanı Barrere ile görüşerek, O'na "Türkiye'nin Musul'dan vazgeçmeyeceğini söylemiş, bu konuda kendilerinin düşüncelerinin ne olduğunu sorduğunda, Barrere'dan Musul İngilizlere aittir, cevabını almış ve bir kez daha hayal kırıklığına uğramıştır". ${ }^{2}$ Türkiye'ye, Musul konusunu ikili görüşmeler yoluyla çözme ve bu yolla İngiliz oyununu bozma teklifini getiren Fransa, ya yukarıda belirttiğimiz gibi Türkiye'ye bir oyun oynamış, ya da menfaat ilişkileri Fransa'nın, İngiliz diplomasisinin oyununa gelerek, Musul konusunda İngiltere'nin yanında yer almasını gerektirmiştir. Fransızların düşüncesi her ne olursa olsun, ortada değişmeyen bir gerçek vardır ki, o da Türkiye'nin Musul konusunda kaderine ve yalnızlığa terk edildiğidir. Artık Musul konusunda lehimizde bir gelişme sağlaması konusunda Fransa'ya güvenmek imkanı da kalmamıştır. Bu olumsuz ortamda 5 Ocak günü, İsmet Paşa tarafindan petrol konusunu görüşmek üzere Londra'ya gönderilmiş olan Muhtar ve Mustafa Şerif

\footnotetext{
${ }^{48}$ Uluğbay, a.g.e., s. 202.

${ }^{49}$ Şimşir, C.I, a.g.e., s.336-337, Belge No:285.

${ }^{50}$ Uluğbay, a.g.e., s.203.

${ }^{51}$ Şimşir, a.g.e., C.I, s.338-339, Belge No:288.

52 Şimşir, a.g.e., C.I, s.348, Belge No:296.
} 
Bey'ler ${ }^{53}, 12$ Ocak günü Lozan'a dönmüşlerdir. Ancak heyet üyeleri Londra'da petrol ayrıcalığı konusunda, yetkili olmayan kişilerle görüştürülmek istenince, temaslar amacına ulaştırılamamıştır. Anlaşıldığı üzere Muhtar ve Mustafa Şerif Bey'lerin Londra temasları, amacına ulaştırılmış olsa idi Lord Curzon'un bilgisi dışında yapılmış olacaktı. Nitekim Lord Curzon, kendisine haber verilmeden, İsmet Paşa'nın Londra'da, heyet üyeleri kanalıyla siyasi temaslar yaptırmaya kalkışmasından fevkalade rahatsız olmuştur. Curzon, Türk Dışişlerine gönderdiği telgrafta kızgınlığını şu cümlelerle ifade etmiştir: "İsmet Paşa, petrol bulunan topraklar dahil Musul vilayetini Türkiye'ye birakmam için başarısız bir şekilde beni ikna, tehdit veya zorlamaya çalışmaktadır. Ben de kabinenin bana vermiş olduğu tavsiye ve yetkilere dayanarak, buna kararlt ve ısrarlı bir biçimde karşı çıkmaktayım. Buradaki başarısızlığını görmesi üzerine, tamamen ilkesiz olarak ve güvenilmez memurların benim haberim olmaksızın Londra'ya göndererek, hükümet yetkilileri ya da özel kişilerle temasa geçerek ve onları etkilemeye çalışarak, benim burada izlediğim politikaya tamamen ters düşecek, haince manevralar içine girmiştir. Bu Türk memurlar, Sir W. Watson Rutherford ve Major Barnett isimli iki milletvekili ile temasa geçmişler ve benim terk etmeye yanaşmadığım topraklar üzerindeki bölgelerde petrol ayrıcalığı müzakerelerine girmişlerdir. Bu memurların temas etmiş oldukları kişilerin yetkisiz olduklarını ve bu temasların hükümetimizce de tanınmadı ๖̆ını bildiririm." ${ }^{54}$

Yaşanan gelişmeler Musul sorunu yüzünden Lozan Antlaşması'nın imzalanmasını tehlikeye sokacak boyutlardadır. İngiltere ise, Musul konusunu konferans dıșına çekerek, sorunu ikili görüșmeler yoluyla çözme niyetini artık iyice ortaya koymuştur. 14 Ocak günü İngiltere'nin İstanbul Yüksek Komiseri, Ankara Hükümeti Temsilcisi Adnan Bey’i ziyaret etmiş, Başbakan Rauf Bey, bu görüşmeyi İsmet Paşa'ya şöyle aktarmıştır: "İngiliz Komiseri Adnan Bey'e Musul konusunda ısrar edeceklerini, ancak bu sorunu konferans dışında ayrı bir şekilde çözüme kavuşturmanın mümkün olduğunu söylemiştir. Adnan Bey, bu yaklaşımın adaletsiz olduğunu, Musul'un Türklere ait olduğunu belirtmissse de, Ingiliz Komiser ısrarla Musul'un Arap şehri olduğunu ifade etmistir. "ᄁs

Lord Curzon petrol meselesini konferans önünde konuşarak, bu zengin doğal kaynaklara yeni taliplerin çıkmasını önlemek amacıyla izledikleri,

\footnotetext{
${ }^{53}$ Muhtar (Çilli) ve Mustafa Şerif (Özkan) Bey'lerin, petrolü vererek, Musul'u almak için Londra'ya gönderilmelerine 'heyet üyelerinden Dr. Rıza Nur karşı çıkmış, ancak İsmet Paşa Dr. Rıza Nur'u dinlemeyerek, Muhtar ve Mustafa Şerif Bey'leri Londra'ya göndermiștir. Dr. Rıza Nur bu girişime, Lord Curzon'u kızdıracağı ve aleyhimize bir durum yaratabileceği endişesi ile karşı çıkmıştır. Dr. Rıza Nur, Hayat ve Hatıratım, C.IV.,s.1037. İsmet Paşa ise, bazı İngiliz temsilcilerinden, Lord Curzon'un yakında görevden alınacağı duyumunu aldığı için, böyle bir yolu denemeyi kendince uygun görmüştür.

${ }^{54}$ Şimşir, a.g.e., C.I, s.380, Belge No:339.

${ }^{55}$ Şimşir, a.g.e., C.I, s.386, Belge No:347.
} 
konuyu konferans dışına çekme projesinin yeni bir aşaması olarak, 17 Ocak günü İsmet Paşa'ya, "Ne Türkiye, ne de İngiltere Musul yüzünden savaşa niyetli değildir. Bu sorunu çözmek için konuyu Lahey'e ya da Milletler Cemiyeti' nin hakemliğine götürelim" teklifini iletmiştir. ${ }^{56}$

Lord Curzon'un Musul konusunu, konferansın 23 Ocak tarihli oturumunda gündeme getirerek, Türkiye'nin Musul konusunda uzlaşmaz bir tavır içerisinde olduğunu dünyaya göstermek ve konuyu hakeme bırakmak stratejisine karşı, İsmet Paşa da bölgede plebisit yapılması taktiğini kabul ettirme anlayışını benimsemiştir. Tarafların bu taktiklerle katıldıkları 23 Ocak 1923 tarihli oturum, Lozan'ın Quchy Şatosu'nda, Lord Curzon'un açış konuşmasıyla başlamıştır. Türk Heyeti bu oturumda, Musul'un Türkiye'ye iade edilmesi görüşünden hiçbir zaman vazgeçmemiş, Lord Curzon da bu isteğe karşı olduklarını birkaç kez belirtmek durumunda kalmıştır. Bu koşullar içinde taraflara, Musul konusundaki karşılıklı görüß̧lerini Konferansa ve tüm dünyaya duyurmak amacıyla söz hakkı verilmiştir.İsmet Paşa, Musul'dan neden vazgeçemeyeceklerini, etnografik, siyasal, tarihi, coğrafi, ekonomik ve askeri nedenlere dayandırarak, şöyle demiştir:

"1-Süleymaniye ve Kerkük sancaklarında Arap unsuru azınlıktadır.

2-Musul merkez sancă̆ında 137.000 Türk ve Kürd'e karşılık, yalnız 28.000 Arap vardir.

3-Musul vilayetinin tamaminda 410.790 Türk ve Kürd'e karşılık, 31.000 müslüman olmayan vardır".

Konferans'ta, Türkler ile İngilizler arasındaki ilk anlaşmazlık, bu nüfus meselesinden dolayı ortaya çıkmıştır. İngiliz temsilci Türk Heyeti'nin sunduğu rakamların doğruluğunu kabul etmediği gibi, 1918 Mondros Mütarekesi'nden sonra İngiliz subay ve memurlarının bölgeye giderek, nüfus sayısını Türkler'den daha doğru saptadıklarını iddia etmiştir. Ayrıca İngilizler, Musul Türkleri'nin Türk değil, Türkmen olduklarını ve dillerinin de İstanbul'da konuşulan Türkçe'den farklı olduğunu savunmuşlardır.

Siyasal açıdan İngilizler şu görüşleri dile getirmişlerdir: "1920'de San Remo'da Irak'ın mandaterliğini üstlenerek İngiltere, müttefiklere karşı bir yükümlülük altına girmiştir. Dolayısıyla İngiltere'nin Irak'a ait bir toprağı bir başka ülkeye verebilmesi mümkün değildir”. Kürtlerin, bölgede Türklerle iyi geçinemediklerini kaydeden İngiliz Heyetine karşı, İsmet Paşa Arapların Musul vilayetinde azınlıkta olduklarını, bu yüzden de Musul'un Irak'a bağlanmasının hem haksız, hem de milletlerin kendi geleceklerini kendilerinin tayin etmesi ilkesine ters bir durum yaratacağını savunmuş, Kürtlerin, Türklerle birlikte yaşamak istemedikleri iddiasının doğru olmadığını, T.B.M.M. Hükümeti'nin Türklerin olduğu kadar, Kürtlerin de hükümeti olduğunu, Kürt temsilcilerinin T.B.M.M. çatısı altında görev yaptıklarını, Türkiye'nin Irak'ta bir manda rejimine hiçbir zaman gerek

\footnotetext{
${ }^{56}$ Şimşir, a.g.e., C.I, s.397,Belge No:362.
} 
duymadığını, İngilizlerin Musul'u Mondros Mütarekesi'nin ilanından sonra haksız biçimde işgal ettiklerini belirtmiştir. Lord Curzon, bölgede plebisite başvuracak bir durumun olmadığını belirttikten sonra, sorunun Milletler Cemiyetine havale edilmesi teklifini yaparak, konuşmasını noktalamıştır.

Lord Curzon'dan sonra söz alan Fransız ve İtalyan temsilcileri de, Musul konusunda İngiliz teklifini desteklediklerini dile getirmişlerdir. İsmet Paşa'nın, İngiliz teklifi üzerindeki düşüncesini öğleden sonra açıklayacağını bildirmesinden sonra konferansin sabahki oturumuna 14.10 'da ara verilmiştir. Sabahki oturum sayesinde İngiliz temsilcisi Türk Petrol Şirketi'nin ayrıcalık haklarının geçerli olduğunu, uluslararası bir konferans zabıtlarına geçirtip, İsmet Paşa'nın reaksiyonunu çekmekle kalmayıp, A.B.D'ni de İngiliz çıkarlarını korumak üzere zabıtlarda yer almasını isteyeceği bir belge vermeye zorlayacaktır. ${ }^{57}$

Saat 18.00 'da başlayan ikinci oturumda ilk sözü alan kişi İsmet Paşa olmuştur. Paşa bu konuşmasında, "Türklerin Musul'u anayurdun bir parçası olarak gördüklerini, Musul'a sahip olma arzularının, petrole sahip olabilme mücadelesi ile özdeştirilmemesini, dünyanın petrole verdiği önemin bilincinde olduklarını, bu nedenle de Musul'u elde ettikten sonra, dünya devletlerini Musul'daki petrolden mahrum etmeyeceklerini söylemis ve bu konuda ileriye dönük söz vermiștir". Lafı Lord Curzon'un ,sorunu Milletler Cemiyetine havale etme önerisine getiren İsmet Paşa, "Curzon'un bu önerisini kabul etmelerinin mümkün olamayacă̆ını, Musul'un kaderini bir hakemin kararına bağlayamayacaklarını kesin bir dille ifade etmiş ve Ingiltere'nin teklifini red etmiştir".

İsmet Paşa'dan sonra söz alan Lord Curzon, teklifinin reddedilmesi karşısında tehditkar bir üslup kullanmıș, "Türkiye'nin tekliflerini incelemediğini bütün dünyanın bilmesi gerektiğini, sorunun Türkiye'nin istediği şekilde çözümlenmemesi halinde, Türk birliklerinin Anadolu'dan Musul'a doğru harekete geçirileceklerini, Türkiye'nin sorunu çözmek için yeni bir savaşa girişece ğini, kendilerinin savașı engellemek için burada olduklarını, Musul'da kan dökülmesi halinde bunun sorumluluğunun İsmet Paşa'ya ait olacağını net bir biçimde vurgulamıştır”.

Lord Curzon'dan sonra söz alan Japon, Fransız ve İtalyan temsilcilerinin de, İngiliz teklifine olumlu baktıklarını ifade etmelerinden sonra İsmet Paşa, bir kez daha söz alarak konuşmacıları cevaplamış ve "bölgede plebisit yapılması doğrultusundaki Türk tezinin sorunun çözümü doğrultusunda en geçerli çözüm olduğunu, plebisitin neden kabul edilmediğini anlamakta zorlandığını" ifade etmiştir.

İsmet Paşa'yı cevaplayan Lord Curzon ise, İngiliz Hükümeti adına girişmek durumunda kalacağı, konunun Milletler Cemiyeti'nin hakemliğine

\footnotetext{
${ }^{57}$ Uluğbay, a.g.e., s.218.
} 
bırakılması doğrultusundaki teklifini hemen uygulamaya koyacağını söyleyerek, konuşmasını noktalamıştır.

A.B.D. Temsilcisi Child ise, konferans sona ermeden önce, ülkesinin görüşlerini anlatan yazılı bir raporun zabıtlara geçirilmesini sağlatarak, Amerikalı petrol şirketlerinin haklarını korumaya çalışmış ve Amerika'nın "Açık Kapı" politikasından vazgeçmeyeceğini belirtmiştir.

Çok sıkıntılı bir gün yaşayan İsmet Paşa, hemen konferansa ilişkin gözlemlerini ve düşüncelerini, M.Kemal Atatürk'e aktaran şu telgrafı kaleme almiştır:

"Bugün son derece buhranlt oldu. Curzon tüm araçların bütün gün boyunca kullandı. Bugün Musul'un siyasi savaş günüdür. Konferansın başında Musul yüzünden dünya barışının tehlikeye girmemesinden yana olduğumuzu belirterek, Musul'u istedim. Curzon, Milletler Cemiyeti'ne başvurmaya karar verdi. O'nun gizli amacl, barlş projesinin tümünü pazarlığa açmadan önce, Musul sorununu çözümlemekti. Çünkü zor duruma düştï ve geri çekildi. Büyük çatışmanın arkasından İspanya Büyükelçisi'nin ziyareti sırasında anladım ki, İtalyan ve Amerikan çevreleri sevinç içindeler. Belki zafer günüdür...Bilesiniz ki çok yorgunum. Üç gece uyuyamadım. Bugünkü Musul çatışmasını dïşündüm. Curzon görüşmelerin kesintiye uğraması konusunda şimdilik geriledi. Devamlı karşı koydu ve tehditlerde bulundu... Benim güzel Gazi Şefim, beni bu kadar imtihana niçin feda ettin. Acaba seni tekrar görebilecek miyim? ${ }^{58}$

Çok karmaşık duygular içerisinde olduğu, M. Kemal Atatürk'e gönderdiği telgrafındaki cümlelerinden anlaşılan İsmet Paşa, daha sonra hükümete sunacağı görüşmelere ilişkin raporunu kaleme almıştır. ${ }^{59}$

23 Ocak 1923 günkü görüşmelerin, Musul sorunu nedeniyle kopma noktasına gelmesi, dünya basınında petrolle ilişkilendirilmiştir. Lord Curzon gazetecilerin, İngiltere'nin tutumunun petrolle ilgisi olup, olmadı̆̆ 1 sorularına muhatap olmuş, bu soruları Curzon," Musul'un Türkiye'ye verilmemesi petrolle ilişkilendiriliyor, ancak Musul vilayetindeki petrolün bizim tezimizle hiçbir ilgisi yoktur. Ben Ingiliz tezini, Irak'taki herhangi bir doğal kaynaktan soyut olarak, kendi tutarlılı̆̆ civarında ne kadar petrol olduğunu, karlı bir şekilde işletilip, işletilemeyeceğini ve hatta buradaki petrolün bir söylentiden ibaret mi olduğunu bilmiyorum...,"60 şeklinde cevaplamıștır. Kendisinin ve ülkesinin Musul ile ilgili politikalarının gerçekleşmesi uğrunda, fütursuzca ülkesinin bu konudaki bilgisizliğini ortaya koyabilen Curzon, Türk Petrol Şirketi'nin ayrıcalığının durumunu soran gazetecilere ise, "Ingiliz Hükümeti ayrıntılı

\footnotetext{
${ }^{58}$ Şimşir, a.g.e., C.I, s.428-429,Belge No:414.

${ }^{59}$ Bu rapor için bak. Şimşir, a.g.e., C.I, s.431-432, Belge No:419.

${ }^{60}$ Uluğbay, a.g.e., s. 222.
} 
incelemesi sonucunda, bu ayrıcalığın geçerli olduğuna inanmış ve bu inancını korumaktadır... Gerek Ingiliz. Hükümeti ve gerek şirket, petrolün bütün dünyayı ilgilendiren bir madde olduğunu, bu konuda tekel yaratma veya iddia etmenin bir hata olacă̆ını bilmektedir. Şirket Ingiliz Hükümeti'nin deste ği ve bilgisi çerçevesinde, bütün ilgili tarafların pay sahibi olabilmeleri için gerekli adımları atmış ve görïșmeler yapmaktadır" diyerek, aslında ülkesinin Musul konusunda ciddi bir çalışma içinde olduğunu söyleyerek, konuşmalarıyla çelişkiye düştügüünü ortaya koymuştur. Böylece Lord Curzon, müttefik devletler arasında petrol yüzünden oluşan çıkar birliğinden güç alarak, müttefik devletleri kendi tezini kabule razı ederek, Musul meselesini konferans dıșını çekme doğrultusunda ilk önemli adımını atmış ve deyimi yerindeyse, 23 Ocak gününün galibi olmuştur.

23 Ocak oturumundan sonra Lozan'da hava gerginleşmiş, konferansın başarıya ulaşmadan dağılacağı haberleri dıș basında geniş bir biçimde yer almağa başlamış,bu gelişme üzerine İsmet Paşa, Ankara'ya bir telgrafla düşüncelerini aktarmış ve onların görüşlerini sormuştur. Paşa telgrafinda, "Musul, adli sistem, mali konular, Doğu Trakya sınırı ve Yunan tazminatı gibi beş temel sorun vardır. Müttefikler, muhtemelen bu noktalar tamamen bizim aleyhimizde olmak üzere, bir iki gïn içinde genel bir antlaşma taslağı vererek, birkaç gün burada bekleyecekler, sonra bizim de konuyu hükümetle görüșmemizi arzu ettikleri için konferansa ara vereceklerdir. Daha sonra antlaşmayı imza etmeye niyetli olduğumuzu ifade ettikten sonra, imza için Lozan'a gelmek isteyeceklerdir.Musul'u Milletler Cemiyeti'ne götürmek, sorunun geleceğini kesinlikle tehlikeye atmak demektir. Hükümetin bu konudaki görüşü nedir?" ${ }^{22}$ demiştir.

Ankara ise, "Müttefik devletlerin karşımızda birleşik bir cephe halinde abluka ve diğer yollarla baskı yapmalarına engel olmak için, aralarındaki birlik ve dayanıșmayı kırmak, Musul sorununun çözümünü her türlü baskı ve zorlamadan uzak tutarak, halkın genel oyuna bıraktığımızı ve petrol konusunda görüşmelere açık olduğumuzu dünya kamuoyuna ilan etmek, Amerika ile ayrıca antlaşma imzalamaya yönelmek" görüşündedir. ${ }^{63}$

M. Kemal ise Lozan'da yaşanan gelişmeleri şöyle değerlendirmiştir: "Kabul etmekle karşılaşacă̆ımız zararla, askeri faaliyete geçmekle elde edeceğimiz sonucu çok dikkatle karşılaştırmak mecburiyetindeyiz. Her halde kararımız olumlu olacaksa, buna konferans kesilmeden ve İsmet Paşa geri dönmeden karar vermemiz gerekir.İsmet Paşa'nın geri dönmesi halinde verilecek bir tek karar vardır, o da askeri faaliyete geçmektir." ${ }^{64}$

Bu arada İsmet Paşa'nın görüştüğü müttefik devletlerin temsilcileri, Paşa'ya Türklerin İngiliz tezini kabul etmeleri yönünde telkinde

\footnotetext{
${ }^{61}$ Ayn1.

${ }^{62}$ Şimşir, a.g.e., C.I, s. 445 , Belge No:437.

${ }^{63}$ Şimşir, a.g.e., C.I, s. 455-456, Belge No:449.

${ }^{64}$ Şimşir, a.g.e., C.I, s. 457, Belge No:450.
} 
bulunmuşlar, A.B.D. temsilcisi de Türkiye ile ikili barış antlaşması yapmaya karşı çıkmıştır.

İngiltere ise, Musul konusunda dünya kamuoyunu etkileyecek girişimlerini sürdürmeyi yoğunlaştırmış, Avrupa basınında Lozan Görüşmeleri'nin kesilmesi halinde Türkiye'nin silaha sarılacağı tezini işlemeye başlamıştır.

Bu arada 31 Ocak'ta, Lozan Konferansı Komisyonları'nın çalışmalarının tamamlanması üzerine, müttefik devletler tarafından oluşturulan taslaklar Türk Temsil Heyeti'ne verilmiş, İsmet Paşa başkanlığındaki Türk Heyeti, bu taslakları inceleyip, verilecek cevabi taslaklar üzerindeki çalışmalarını sürdürmüşlerdir. Bu çalışmalar sırasında Türk delegasyonu arasındaki görüş ayrılıkları büyük ölçüde ortadan kalkmıștır. Müttefiklerden alınan taslaklar sonucunda oluşturulan Türk Heyeti'nin görüşleri Ankara'ya da bildirilmiş ve onlardan görüşleri sorulmuştur. Başbakan Rauf Bey'in, Atatürk'ün görüşleri doğrultusunda, İsmet Paşa'ya ilettiği görüşler aynen şöyledir:

"Konferansin kesilmesi durumunda, askeri harekata başlanıp, başlanmayacă̆ı konusunda Fevzi Paşa (Çakmak) ve Kazım Paşa (Karabekir) ile aynı görüş̧teyim. Konferans iki şekilde dağılabilir. 1Düşmanlarımız uygulanması zor bir tasarı önerirlerse, bunu reddettiğimiz taktirde konferansın son bulacağını bildirirler. 2-Dïsmanlar yine bir taslak verip, bizden bir karşı tasarı beklediklerini hissettirirlerse, bu durumda konferans kesilmiş değil, ertelenmiş olur. Birinci olasılığın gerçekleşmesi halinde, askeri harekata girişmek doğal ve zorunludur. İkinci olasilığın gerçekleşmesi halinde ise, askeri harekata girişmek, bizi müttefik devletler önü̈nde sıkıntıya sokar. Çünkü düşmanlarımızın sorumluluğu bize yüklemek için bu yolu seçmeleri kuvvetle muhtemeldir. Bir üçüncü ihtimal daha vardır, o da Konferans şu veya bu şekilde dağılıp da, Ingilizler 16 Mart olayına benzer bir durum yaratırlarsa, bu da önemli bir savaş nedeni olur.. Askeri haekat durumunda diplomatik nedenlerden dolayı Lozan'dan ayrlmantz uygun olur." 65

Türk Heyeti'ne müttefik devletlere karșı teklifini iletmek üzere verilen süre 4 Şubat günüdür. Aynı gün konferansa katılan heyetler, Lord Curzon'la bir araya gelmişler, son durumu görüşmüşler, ancak sonuç değişmemiştir. 6 ve 7 Şubat günleri İsmet Paşa, Lozan'dan ayrılmadan önce, müttefik devletler temsilcileri ile son bir kez daha görüşmüş, bir bildiri yayınlayarak, konferansın kesilmediğini, heyet üyelerinin hükümetleri ile görüşmek üzere başkentlerine gitmek durumunda oldukları ${ }^{66}$ mesajını vermiş, arkasından da heyet üyeleri ile birlikte Ankara'ya hareket etmiştir.

\footnotetext{
${ }^{65}$ Şimşir, a.g.e., C.I, s. 470-471, Belge No:471.

${ }^{66}$ Şimşir, a.g.e., C.I, s.502, Belge No:504.
} 
Böylece Lozan Konferansı'nın ilk tur görüşmelerinde Dr. Rıza Nur'un anılarından edindiğimiz bilgilere göre, özel görüşmelerde İngilizler Türk Heyeti'ne Süleymaniye sancağını tamamen bırakmayı önermişler, ancak Tevfik Bey "Süleymaniye'den ne çıkar? Buralar dağlıktır. Musul olmayınca oralara gidilemez. Başa bela olur" diyerek, İsmet Paşa'yı da etkilemiş ${ }^{67}$, belki Süleymaniye'nin alınmasıyla, Musul konusunda bir ilerleme kaydedebilme ihtimali mevcut iken, bu şans da yitirilmiş ve Türkiye Musul konusunda kendisini tatmin edecek bir karar elde edememiştir.

\subsection{LOZAN GÖRÜŞMELERI'NIN KESINTIYYE UĞRAMASI (INKITA DÖNEMI)}

Lozan Konferansı'ndaki görüşmeler hakkında B.M.M'ne ayrıntılı bilgiler, 1 Ocak 1923 tarihli gizli oturumda,Lozan'dan yeni dönen Türk heyetinin üçüncü delegesi durumundaki Trabzon Milletvekili Hasan (Saka) Bey tarafından verilmiştir. Üzerinde tamamen anlaşmaya varılan ve tartışmaları hala devam eden konular hakkında Meclis Genel Kurulu'na bilgi veren Hasan Bey, özellikle Kapitülasyonlar ve Musul konusunda taraflar arasında çekişme yaşandığını kaydetmiştir. ${ }^{68}$ Lozan konusundaki gizli oturumlar, 20, 25, 28 ve 29 Ocak 1923 günlerinden 5, 7, 21 Şubat ile 2-6 Mart tarihlerine kadar devam etmiştir. Bu gizli görüşmeler sırasında özellikle muhalefet, delegelerin ve hükümet başkanının yaptığı açıklamaları yeterli bulmamıştır. Trabzon Milletvekili Ali Şükrü Bey, "Bu bilgilerin hepsini zaten gazetelerden ögrrendiklerini, kendilerine bildiklerinden noksan mulumat verildiğini" kaydetmiş, Rauf Bey ise cevaben, " $O$, sizin görüşünüz. Üçyüz elli kişinin, aynı mesele üzerinde aynı kanaati taşıması mümkün değildir.Bunun dünyada örneği görülmemiştir. Biz bütün konferans boyunca telgrafin bir ucunda delegelerimiz, diğer ucunda hükümetimiz, her maddeyi saatlerce inceledik" demiştir ${ }^{69}$ Meclisteki muhalefet, görüşmelerin kesintiye uğramasının da verdiği cesaretle, görüldüğü üzere mecliste sesini yükseltmeye başlamıştır. Bir kısım milletvekilleri belki Lozan'da Türkiye'nin kaderine yön verecek kadroda yer alamamış olmalarının rahatsızlığı ile, bir kısmı da Ankara'daki meclisi, kuvvetler birliği esasına göre oluşturulmuş, bir geçiş dönemi meclisi olduğu için, demokratik ülkelerin meclislerinden farklı bir yapıda görmüşler ve hükümetin Lozan'da üstlendiği yürütme görevinde, tam yetkili olarak rol oynamak istemişlerdir. ${ }^{70}$

Meclisin 21 Şubat 1923 tarihli gizli oturumunda, Türkiye'ye yeni dönmüş olan İsmet Paşa, Lozan Konferansı ile ilgili olarak meclise bilgi vermiştir.Uzun bir konuşma yaparak, meclisi Lozan konusunda bilgilendiren

\footnotetext{
${ }^{67}$ Riza Nur, a.g.e., C.IV., s. 1030

${ }^{68}$ T.B.M.M. Gizli Celse Zabıtları, C.III., Devre 1, İçtima 3, (Türk.İş. Bank.Yay.), Ankara, 1985,s.1169 vd.

${ }^{69}$ T.B.M.M. Gizli Celse Zabıtlan, C,IV., Devre 1, İçtima 4, s.33.

${ }^{70}$ Popüler Tarih Dergisi, Şubat 2000.
} 
İsmet Paşa, müttefiklerin Türk Heyeti'ni tehdit ettiğini söyleyerek, konuşmasının Musul ile ilgili bölümünü şöyle sürdürmüştür:

"Bugün Musul, bilvasıta veya bilavasıta İngiliz işgali altında bulunuyor. Bu Musul meselesinin bize iadesi mevzubahis oldu. Bunu başlangıçta açık celsede ele almak vardı. Özel mülakatımla alakadar olan İngiliz mümessili ile görüştügüumüzde, bunu aramızda bir hal yoluna koymak için çalışalım dedi, kabul ettim.Özel bir biçimde pek çok kereler fikir teatisinde bulunduk. Sonra karşıllklı birbirimize muhtıralar verilmeye başlandı ve mesele basına aksedince kamuoyu Musul meselesi üzerinde tahrik oldu. Mücadele ettik. Muhtıralarında dayanak yapmak istedikleri delillere karşı ırki, coğrafi, iktisadi, siyasi ve bir takım delillere dayanarak, ne cevap gerekiyorsa onu verdik ve haklılığımızı dünyaya duyurduk. Bu meselede birbirimizi ikna etmek ihtimali yoktur. Tekrar komisyonda bu konu görüşülsün dediler, kabul ettik. Tekrar komisyona çıktı. Biz Musul üzerinde kendileriyle anlaşalım, bir çıkış yolu bulalım dedik. Fakat onların ekonomik gelişmelerini să̆lamak, petrollerinden faydalanmak vs. gibi menfaatleri varsa, veyahut bir takım unsurları kendi aleyhlerinde tahrik edeceğimizden endişeleri varsa, onu da tatmin edelim, bir hal yolu bulalım dedik. Onlar da bir çözüm yolu artyorlardı. Musul şehrini kendi ellerinde muhafaza etsinler, eğer biz ekonomik menfaatlerinden, petrollerinden dolayı vermiyorsak, herkese verdikleri gibi bize de bir hisse versinler. Genel oturumda Musul söz konusu olduğu zaman, mesele bu safhada idi. En nihayet son ve kati olarak bütün müttefikler, birleşik bir cephe oluşturarak, inkıta ile tehdit ettiler. Bizi Musul meselesinde geri adım atmağa mecbur ettiler..."71

İsmet Paşa'nın açıklamalarından sonra, Lozan görüşmeleri ve Musul konusu yüzünden, 27 Şubat tarihinden itibaren mecliste sert tartışmalar yaşanmıştır. T.B.M.M'nde muhalefet rolünü üstlenen ikinci grup milletvekilleri, "Musul verilemez, gerekirse bu uğurda savaşırız" anlayışı içinde hareket etmişlerdir. Bu anlayış içinde defalarca söz alan bazı milletvekilleri, İsmet Paşa'ya ve Vekiller Heyeti'ne yönelik çeşitli suçlamalarda bulunmuşlardır. Bu milletvekillerinden özellikle Hüseyin Avni Bey ve Ali Şükrü Bey'ler, Lozan görüşmelerinde “Misak-ı Milli'den taviz veriliyor" iddiası ile endişelerini dile getirmişlerdir. Ali Şükrü Bey, 5 Mart 1923 günü," Muhammed'in süngüsünün vazifesini layıkıyla yaptığı, ancak $o$ süngünün kazandı̆̆ı zaferin hep yeşil masa başında kaybedildiği, yine tarihin tekerrür ettiğ i " ifadeleriyle başlayan konuşmasında, "müzakereye davet edilen taraf olmamıza rağmen, görüşmeler sırasında ilk teşebbüsün düşmanlara bırakılmasını anlayamadığını" ifade etmiş ve şöyle demiştir:

"Sonra öyle bir vaziyete gelinmiştir ki, Lord Corzon daima bize hamle yapmıştır.Bizimkiler daima savunmada kalmışlar, bir kez cür'et gösterip de hamle yapamamışlardır". Lozan'a gönderilen murahhas heyetinin artık

\footnotetext{
${ }^{71}$ T.B.M.M. Gizli Celse Zabıtları, C.III,s.1292.
} 
işinin bittiğgine değinen Ali Şükrü Bey, "...Artık mesele heyet-i murahhasanın elinden çıkmış, Vekiller Heyeti'nin eline geçmiştir. Heyet-i Vekile bütün sorumluluğu üstlenmiş, teklif edeceği mukabil projeyi müdafaa ediyor... Binaenaleyh bugünkü vaziyet, murahhas heyetinin vazifesinin bitmesinden ibarettir". Musul meselesinin çözümünü bir sene sonraya bırakan ve dolayısıyla Misak-1 Milli'ye ters düşen bir kararı alan murahhas heyetinin, bu kararını Rauf Bey'in üç saat süreyle mecliste savunmasını da eleştiren Ali Şükrü Bey," Ben olsaydım, beni üç ay oyalayan, üç ay zarfinda bana Türkiye'de tahşidat yapmaya meydan verdiren devletlere, tali komisyonlarda bir çok meselede anlaştık dedikten sonra, bana verdikleri projede hiç konuşmadığımız meseleleri gördüğüm zaman, paçavra gibi suratlarına atıp, bizimle alay mı ettiniz. Üç aydır müzakere edip anlaştı ğımız bu mu idi, bu konuşmadığımız meseleleri nereden koydunuz, diye bütün cihana karşı suratlarına fırlatırdım" demiştir. Konuşmasında artık barışı gerçekleştirme şansının kalmadığına da değinen Ali Şükrü Bey, " $O$ zaferin gerektirdiği sulhü elde edebilme firsatı bugün ebediyen yok olmuştur. Harbi göze aldık mı, Trakya'nın bir defa daha çiğnenmesi ve İstanbul'un tamamiyle perişan olması söz konusu olur ki, içimizde bunu göze alabilecek hiçbir kabadayı yoktur" ifadelerini kullanmıştır. Musul meselesinin çözümünü bir sene sonraya bırakmanın Musul'u kaybetmekle aynı anlama geldiğine de değinen Ali Şükrü Bey, "Musul'u bir sene sonraya birakmak, bir Misır yapmak, sonuçta orayı kaybetmek demektir. Bu da Girit gibi gidecektir.Dolayısıyla Musul'u bırakmak doğru de ğildir.Ben Musul'da bulunmadım. Oraları bilmiyorum.Fakat okuduğum üzerine söylüyorum. Süleymaniye, Kerkük, Zaho filan bilmem nereleri vardır. Buraların tali komisyonda bize verilmesi görüşülmüss ve bize bırakılmış efendiler! Işittiğime göre bu saydığım kısım, Musul'un üçte ikisi imiş.(Onda dokuzu sesleri)...Bakını bilenler onda dokuzu diyorlar. Tali komisyonda buraların bize verilece ği kabul edilmiş iken, bugün bütün Musul'un bir sene sonraya ertelenmesini ayıp değil ya anlayamıyorum... Musul meselesi Milletler Cemiyeti'ne havale edilince, bütün İngiliz murahhaslarının ve sömürgelerinin murahhaslarının orada oy haklarının olması nedeniyle, Musul tamamen gitmiştir. Efendiler o halde soruyorum. Hepsini kaybetmektense, hiç olmazsa dörtte üçünü alsaydık, bizim için daha iyi olmaz miydl?"72

Erzurum Milletvekili Hüseyin Avni Bey ise konuşmasında," Karşımızdaki yegane düşmanın Ingilizler olduğunu, Milletler Cemiyeti'nde her milletten temsilci bulunmadı̆̆ için, bu teşkilata güveninin olmadığını, Musul meselesinin Milletler Cemiyeti tarafindan bizim lehimizde çözümünün mümkün olamayacă̆ını, İngilizlerin Musul'u alıp orada bir Kürt hükümeti oluşturmak ve memleketimizi parçalayarak, sonuçta bir Ermenistan teşkil etme gayreti içerisinde olduklarını" belirtmiş, "gerek Vekiller Heyeti'nin, gerekse T.B.M.M'nin Misak-ı Milli'den zerre kadar fedakarlıkta bulunması

\footnotetext{
${ }^{72}$ T.B.M.M. Gizli Celse Zabitlan, C.IV, s,130 vd.
} 
halinde, böyle bir gelişmeye ortam hazırlanacağını" kaydetmiştir. "Kararlarında direnenlerin milleti böyle kötü bir sona sürükleyeceklerini, bu yüzden çekip gitmelerinin milletin hayrına olduğunu" ifade etmiştir. ${ }^{73}$

İzmit Milletvekili Surrı Bey ve Erzurum Milletvekili Durak Bey ise, Ali Şükrü ve Hüseyin Avni Bey'ler kadar sert bir üslupla olmasa da, Musul konusundaki rahatsızlıklarını gizli oturumda dile getirmişlerdir. Sırrı Bey konuşmasında, "İsmet Paşa'nın Misak-ı Milli anlayışı ile kendilerinin Misak-ı Milli anlayışının farklı olduğunu kanaatine kapıldı ğını" belirtmiştir. ${ }^{74}$ Durak Bey ise, "Musul meselesinin çok önemli olduğunu, çünkü orada bir Kürt Hükümeti kurulması suretiyle, bugün Erzurum'un sekiz saat kadar güneyinde, Türkiye için önemli bir tehdit oluşturulduğunu, Musul sorununu, bir yıl zarfında çözülememesi halinde Milletler Cemiyeti'ne bırakma mantı̆̆ını anlayamadı ğını" kaydetmiştir. ${ }^{75}$ Bitlis Milletvekili Yusuf Ziya Bey de bir Kürt olarak, "Musul'u Türkiye'den ayırmanın, bir insant ikiye bölmek veya herhangi bir parçasını koparmakla aynı anlama geleceğini, bölgede de Türkiye'den kopma anlayıșının mevcut olmadığını" savunmuştur. ${ }^{76}$ Meclise bir soru önergesi veren Siirt Milletvekili Mehmet Kadri Bey ise, İsmet Paşa'ya “Musul konusunun bir sene zarfında İngiltere ile aramızda çözülememesi halinde, Milletler Cemiyeti'ne havale edilmesi hususunda, Vekiller Heyeti'nin kendisine yetki verip vermediğini”' sormuştur. İsmet Paşa ise cevaben, "Evvelce böyle bir durum söz konusu olmadığı için, Heyet-i Vekile'nin kendisine böyle bir talimat ve yetki vermediğini, görevinin Musul'u elde etmek olduğunu, bu amaçla çalıştı ğını" söylemiştir."

Lozan konusunda meclisin gizli oturumunda yapılan karşı konuşmaları irdelediğimizde, milletvekillerinin genelde, Misak-1 Milli’den taviz verilmiş olunduğu izlenimine kapılmış oldukları görülmektedir. Milletvekillerinde rahatsızlık yaratan diğer konular da, Lozan'a giden heyetin orada haklarımızı iyi savunamadığı, yeterli politik mücadele veremediği, yetkilerini aştı̆̆ gerekli konularda T.B.M.M'ne danışmadığı ve Lozan Görüşmeleri ile ilgili olarak meclisin yeterince aydınlatılmadığı konularıdır. Görüşmelerde T.B.M.M'ne başkanlık eden Ali Fuad Paşa hatıralarında, "Meclis hakikaten aydınlatılmamışt . Müttefiklerin yanlış tercüme ve tabedilmiş projesinden başka elde yazılı bir şey yoktu" demektedir. ${ }^{78}$ Ali Fuad Paşa tartışmalar sırasındaki meclis atmosferini şu cümlelerle ifade etmektedir:

“Mebuslar... hükümeti ihmalkarlıkla itham ediyorlardı.Gerek hükümet ve gerekse başmurahhas İsmet Paşa'yı mes'ul tutmak yoluna gidiyorlardı. Konuşmaların hemen hepsi şiddetli ve sinirli idi. Mebusların Misak-l

\footnotetext{
${ }^{73}$ T.B.M.M. Gizli Celse Zabıtlan, C.IV,s.93 vd.

${ }^{74}$ T.B.M.M. Gizli Celse Zabitları, C.IV,s.106 vd.

${ }^{75}$ T.B.M.M. Gizli Celse Zabitlan, C,IV,s.150 vd.

${ }^{76}$ T.B.M.M. Gizli Celse Zabıtlan, C.IV,s.87-90.

${ }^{77}$ T.B.M.M. Gizli Celse Zabitları, C,IV,s.80.

${ }^{78}$ Ali Fuad Cebesoy, Ali Fuad Cebesoy'un Siyasi Hatıraları, İstanbul, 1957, s.246.
} 
Milli'den bazı fedakarlıklar yapılmak suretiyle hazırlanan mukabil projenin müttefiklerce kabulü halinde, meclisin millet önünde düşeceği durumdan son derece telaşlandiklart belli oluyordu. Hatiplerin birbirinden heyecanll ve sinirli konuşmaları, meclisin havasını büsbütü̈ karıştırmıştı"79 Önce milletvekillerini Rauf Bey iknaya çalıșmış, ancak Rauf Bey'in (Orbay) gizli oturumda, Musul meselesinin önce taraflar arasında çözümlenmesini, bunun gerçekleştirilememesi durumunda Milletler Cemiyeti'ne havale edilmesini savunması ve İsmet Paşa lehinde bir tavır takınması sinirleri büsbütün germiştir. Rauf Bey özetle şöyle demiştir:

"Musul'u hemen alacă̆ız fikrinde tsrar edersek, mutlaka ordu ile almamız gerekir. Ç̈̈nkü Musul'u siyasi yollardan almak imkanı olmadı̆̆ına murahhas heyetimiz kani olmustur ve bize izah edince biz de kani olmuşuzdur. Ĕger bir sene tehir edersek ve bu bir sene zarfinda kuvvetle çalışırsak, gerçek teşebbüste bulunursak siyaseten Musul'u kazanmak imkanı doğar (Ne ile sesleri) ${ }^{80}$ Rauf Bey'in de meclisteki bu ortamda sinirleri iyice gerilmiş olacak ki, konuşmasının devamında rest çekmiş ve "Yapamayacağımıza kani olanlar, yani bu şekilde yapılmasını istemeyenler, adem-i itimat verir. Bu şekilde yapılmasın isteyenler itimat verir. Kaybedersek basskaları gelir. Onlara da elimizden gelen azami fedakarlık ve yardımı yaparız ${ }^{31}$ demiştir.

Meclisteki bu gergin havayı yumuşatmak Mustafa Kemal Paşa'ya düşmüştür. Mustafa Kemal Paşa mecliste 6.31923 'te yaptığı konuşmada, "Elinizde bulunan tercümesi çok yanlış ve eksik olan bu Sulh Projesi'ni bizim için de kabul etmek mümkün değildir... Çünkü doğrudan doğruya bağımsızlığımıza zarar verecek sartlar içermektedir. Ĕ̆er Itilâf Devletleri projeyi bize bu şekli ile kabul ettirmekte israr ederlerse, o zaman harp ederiz. Ancak bu noktaya gelmeden önce, her yolu denemek, mümkün olduğu kadar harpten kaçınmak hepimizin arzusudur... Lozan'da konferans müzakereleri kesilmedi. Her devletin murahhas heyetleri kendi memleketlerine gittiği gibi, bizim heyetimiz de buraya geldi. Murahhas heyetimiz, Vekiller Heyeti'ne karşı sorumludur. Vekiller Heyeti, murahhas heyetimizi dinledikten sonra, yeni talimat vermek hususunda tereddüt duyduğu bir takım noktalar dolayısıla yüce heyetinize geldi... Musul meselesinin hallini, harbe girmemek için bir sene sonraya ertelemek demek, ondan vazgeçmek demek değildir.Belki amacımıza ulaşmak için daha kuvvetli olacağımız bir zamana kadar beklemek demektir. Musul meselesini bugün halledeceğiz, ordumuzu yürüteceğiz, bugün alacă̆ız dersek, bu mümkündür. Fakat Musul'u aldıktan sonra, hemen sorunun biteceğine kani olamayız" $"$ 2

\footnotetext{
${ }^{79}$ Cebesoy, a.g.e., s.247-248.

${ }^{80}$ T.B.M.M. Gizli Celse Zabıtları, C.IV,s.86.

${ }^{81}$ T.B.M.M. Gizli Celse Zabıtları, C.IV,s.190.

${ }^{82}$ T.B.M.M. Gizli Celse Zabitlan,C.IV,s,173 vd.
} 
Mustafa Kemal Paşa görüldügüü üzere milletvekillerine hak veren, yumuşak bir üslupla ortamı yatıştırmıştır.Mustafa Kemal Paşa'nın Musul'un Misak-1 Milli sınırlarına dahil edilmesinde kararlıdır. Paşa 25.12.1922'de "Le Journal" muhabiri Paul Herriot'a verdiği beyanatta Musul konusundaki bakış açısını şöyle izah etmiştir:

"Musul vilayetinin milli hudutlarımıza dahil olduğunu defalarca ilan ettik. Lozan'da bugün karşımızda yer alan devletler bunu çok iyi bilirler. Vatanımızın hudutlarını tayin ettiğimiz zaman büyük fedakarlıklara katlandık..Artık milli arazimizden en ufak bir parçasını bizden koparmaya çalışmak, çok haksız bir hareket olur.Buna kesinlikle izin vermeyiz ${ }^{83}$

Mustafa Kemal Paşa Lozan Konferansı'nın kesintiye uğramasından ve İngilizlerin tehditlerinden sonra da bu düşüncelerinden vazgeçmemiştir.

Mustafa Kemal Paşa'nın meclisin gizli oturumunda 6.3.1923 tarihinde yaptığı konuşmasından sonra, Saruhan Milletvekili Reşat Bey'in Lozan'a giden murahhas heyetine ve Vekiller Heyeti'ne itimat edilmesi ve müzakerelerin sona erdirilmesi yolundaki önergesi oylamaya konulmuş, 190 üyenin katıldığ1 oylamada, 170 milletvekili olumlu, 20 milletvekili ise olumsuz oy kullanmıştır. ${ }^{84}$ Íkinci gruba mensup 60 milletvekili de oylamaya katılmamıştır.

\section{5 İKINCİ DÖNEM LOZAN GÖRÜŞMELERİ VE MUSUL MESELESI}

T.B.M.M. Hükümeti 8 Mart 1923'de Müttefikler'in anlaşma tasarısına karşı, kendi anlaşma tasarısını Müttefik Devletler'e bildirmiş, Türkiye'ye 28 Mart'ta cevap veren Müttefikler, Konferans'ın Lozan'da 23 Nisan 1923'de toplanmasını teklif etmişlerdir. Bu teklifin kabul edilmesi üzerine Lozan Görüșmeleri'nin ikinci dönemi, 23 Nisan 1923 günü başlamış ve üç ay süren çalışmalar sonucunda 24 Temmuz 1923'de Lozan Antlaşması'nın taraflarca imzalanması ile son bulmuştur. Birinci dönem Lozan Görüşmeleri sonunda Türkiye'nin Musul meselesinin konferans dışında taraflar arasında ikili görüşmeler yoluyla çözümlenmesi, bu müzakerelerde sonuca ulaşılamaması halinde sorunun Milletler Cemiyeti'ne götürülmesini kabul etmiş olması yüzünden, ikinci dönem Lozan Görüşmeleri'nde Musul ve petrol konusu doğrudan gündeme gelmemiştir. ${ }^{85}$

İngiltere'nin ikinci dönem görüşmelerde de Musul konusundaki uzlaşmaz tavrını sürdürmeye devam etmesi yüzünden İsmet Paşa, barışın yapılmasına engel olmamak için, sorunun bir yıl içinde taraflar arasında görüşülmesine

\footnotetext{
${ }^{83}$ Söylev ve Demeçler, C.III.,s.56.

${ }^{84}$ T.B.M.M. Gizli Celse Zabitlan, C.IV ,s.190.

${ }^{85}$ Uluğbay, a.g.e., s.239.
} 
razı olmuş ve Musul sorunu Lozan Konferansı gündeminden çıkarılarak, antlaşmanın 3/2. maddesi şöyle düzenlenmiştir:

"Türkiye ile Irak arasındaki sınır, bu antlaşmanın yürürlüğe girişinden başlayarak, dokuz ayllk bir süre içinde, Türkiye ile İngiltere arasında dostça bir çözüm yolu bulunarak halledilecektir.Öngörülen bu süre içinde taraflar arasında bir anlaşmaya varılamazsa, anlaşmazlık Milletler Cemiyeti Meclisi'ne götürülecektir. Sinır çizgisi konusunda alınacak kararı beklerken, Türk ve Ingiliz Hükümetleri, kesin geleceği bu karara bağlı olan toprakların şimdiki durumunda herhangi bir değişiklik yapacak nitelikte, hiçbir askeri ya da başka bir harekette bulunmamayı karşılıklı olarak kabulleneceklerdir" ${ }^{\prime \prime 6}$

Lozan Antlaşması'nın ilk B.M.M'nde Misak-ı Milli'den taviz verildiği gerekçesiyle onaylanmayacağı aşikardır. İkinci B.M.M'si çalışmalarına bașladığında, ilk B.M.M'ndeki muhalif milletvekillerinin, büyük ölçüde ikinci B.M.M'nde yer almamış olmasına rağmen, yine muhalif bir grup mevcuttur.Mustafa Kemal Paşa'nın antlaşmanın imzalanması yönünde tavır koyması, muhalefeti sindirmiş ve 23 Ağustos 1923'de Lozan Antlaşması T.B.M.M tarafından onaylanmıştır.

\section{LOZAN GÖRÜŞMELERI SONRASINDA MUSUL MESELESI}

İngiltere, Musul'u kendi hakimiyetine geçirecek gelişmeleri bir an önce başlatmak arzusundadır. Bu amaçla 5 Ekim 1923 günü İngiliz Hükümeti, Ankara'ya başvurarak, Lozan Antlaşması'nın 3/2 maddesinin öngördüğü ikili görüşmelerin bir an önce başlamasını ve söz konusu maddede yer alan dokuz aylık sürenin, antlaşmanın yürürlüğe girmesinden değil, bu başvuru tarihinden itibaren geçerli olmasını önermiştir. ${ }^{87} \mathrm{Bu}$ başvuru üzerine iki ülkenin yetkilileri arasında yapılan görüşmeler sonunda Musul ile ilgili ikili görüşmelerin 19 Mayıs 1924'de İstanbul'da yapılmasına karar verilmiştir. İngiltere bir yandan bir an önce ikili görüşmelerin başlatılmasını sağlamaya çalışırken, bir yandan da Güneydoğu Anadolu'da ortalığı karıştırma çabaları içerisine girmiştir. Bu durumdan rahatsız olan Ankara, 31 Aralık 1923 günü Dışişleri Bakanı İsmet Paşa'nın imzası ile Londra Büyükelçisi Yusuf Kemal (Tengirşenk) Bey'e “İngilizlerin gerek Musul, gerek Iran sınırında izledikleri Kürt ve Nesturi siyaseti aleyhimizedir. Ingilizlerin bu politikalarından duyduğumuz rahatsızlık kendilerine iletilmelidir" şeklinde bir talimat vermiştir. ${ }^{88}$

\footnotetext{
${ }^{86}$ Oran, a.g.e., C.I.,s.262.

${ }^{87}$ Ömer Kürkçüoğlu, Türk İngiliz İlişkileri (1919-1926), A.Ü. Siyasal Bilgiler Fak. Yay., s.293.

${ }^{88}$ T.C.Dışişleri Bakanlığı, Cumhuriyetin İlk On Yılı ve Balkan Paktı (1923-1934), (Türkiye Dış Politikasında 50 Yıl serisi),s.78.
} 
Türkiye bir yandan Musul meselesinin çözümüne hazırlanırken, bir yandan da çok önemli inkılap hareketlerini gerçekleştirmek üzeredir. Halifeliğin Kaldırılmasını öngören yasanın çıkarıldığı gün, Tevhid-i Tedrisat yasası ile birlikte Osmanlı hanedanı üyelerinin yurt dışına çıkarılmasını öngören yasayı da kabul etmiştir. Bu yasaların çıkarılmasının ülke genelinde yarattı̆̆ı hava, Musul'u elde etmekten başka bir düşünceleri olmayan İngilizler tarafından ne yazık ki kullanılacaktır.

Ankara Hükümeti bu gelişmeler yaşanırken, İstanbul'da yapılacak olan konferansta Fethi (Okyar) Bey'in Türkiye'yi temsil etmesine karar vermiştir. Hükümet 26 Nisan 1924 günü konferansta izleyecekleri politikayı şekillendirmiş ve Fethi Bey'e "Türkiye-Irak sınırının, Süleymaniye, Kerkük ve Musul bölgesinin Türkiye sinırları içinde kalacak şekilde belirlenmesi, bu isteğin kabulünü sağlamak üzere İngiltere'ye yöre petrollerinden ortaklık teklif edilmesi" yönünde talimat vermiştir. ${ }^{89}$ Türkiye politikasını, İngiltere'ye petrol ortaklığı teklifinde bulunmak suretiyle ikna edip, Musul konusunda kendi lehinde bir gelişme sağlayabileceği stratejisine dayandırmıștır.

Türkiye hazırlıklarını sürdürürken, İngiltere'de ikili görüşmelerde ülkesini Bağdat Eski Yüksek Komiseri Sir Percy Cox'un temsil etmesini kararlaştırmıştır. Sir Percy Cox'a, Türkiye ile yapılacak ikili görüşmelerde "Irak'ın kuzey sinırı için (Nesturi ${ }^{90}$ yurdu olarak tahsis edilmek üzere) Hakkari vilayetini de içine alacak bir hatt önermesi, Türkiye'nin hemen reddetmesi beklenen bu öneri karşısında direnmesi talimatı" verilmiştir. İngilizlerin temsilcilerine böyle bir talimat vermelerinin altında yatan en önemli sebep, Nesturileri korumaktan çok, ikili görüşmeleri çıkmaza sokup, meseleyi bir an önce Milletler Cemiyeti'ne götürmektir. Çünkü İngiliz Hükümeti başından beri meselenin Milletler Cemiyeti'ne götürülmesinden yanadır. Nitekim, İngiliz Dışişleri Bakanlığı Ortadoğu Uzmanı W.G. Osborne'un "Görüşmelere başlayacağız da ne olacak. Aynı tartışmalar bir kez daha tekrarlanacak. Nasıl olsa nihai ve bizim için en uygun çözüm Milletler Cemiyeti'nde sağlanacaktır" sözleri bu görüşü doğrulamaktadır. ${ }^{91}$

\footnotetext{
${ }^{89}$ Cumhuriyetin İlk On Yllı, s.81

90 Nesturiler, Osmanlı Devleti'nin Doğu ve Güneydoğu Anadolu'da yaşayan yerleşik Hıristiyan uyruklarındandır. I. Dünya Savaşı yıllarında Çarlık ordularının Van ve çevresini işgalleri sırasında, çevre halkına kötü davranan Nesturiler,1917'de Çarlık Rusyası ordularının bölgeden çekilmesi üzerine İran'a kaçmak zorunda kalmışlardır. 1917 yılında Urumiye'ye gelen İngiliz Yüzbaşısı Gracey, o tarihlerde nüfusu 150.000 kadar olan Nesturiler'den, Osmanlılara karşı savaşa devam etmelerini istemiştir.Savaş sonunda İngilizlerle birlikte Irak'a gelen ve sayıları 35.000 dolayında olan, Musul ve çevresine yerleştirilen Nesturiler'e İngiliz idaresi önceleri Kanada'ya göçmeleri konusunda baskı yaptıysa da, sonra Irak'ta kalmalarını kabul etmiştir. Uluğbay, a.g.e., s.246.

${ }^{91}$ Mim Kemal Öke, Musul Meselesi Kronolojisi (1918-1926), Türk Dünyası Araştırmaları Vakfı, İstanbul,1987, s.124.
} 
Haliç (İstanbul) Konferansı'nın toplanmasından bir süre önce Türkiye'nin Londra Büyükelçisi Yusuf Kemal Bey, İngilizler Dıșişleri'ne bir nota vererek, Musul ve çevresinin İngiliz Hava Kuvvetleri'nce bombalanmaya devam etmesini, Nesturilerin silahlandırılarak Türkiye'ye saldırtılmalarını ve Musul çevresindeki aşiretlere baskı yapılmasını protesto etmiş, ancak İngiliz Hükümeti bu iddiaları kabul etmemiştir.

Haliç Konferansı'nın 19 ve 21 Mayıs tarihli oturumlarında taraflar, Lozan'daki tezlerini tekrarlamışlardır. 24 Mayıs günkü üçüncü oturumda ise İngilizler Lozan'daki iddialarını tekrarlamaktan öte, Hakkari ilinin, Beytüşşebab, Çölemerik(bugünkü Hakkari il merkezinin eski adı) ve Revanduz kazalarının da Nasturi yurdu olarak Irak'a bırakılmasını Türkiye'den talep etmiştir. Fethi Bey bu isteğe şiddetle karşı çıkmış, İngilizlerin bu konudaki ısrarlı tutumunu 3 Haziran günkü oturumda da devam ettirmeleri yüzünden, Haliç Konferansı 5 Haziran günü bir sonuç alınamadan dağılmıştır.

$\mathrm{Bu}$ gelişme Türkiye için sıkıntılı günlerin başlangıcı olmuştur. Mussolini yönetimindeki faşist İtalya, Türkiye'nin Musul'u kuvvet kullanarak almaya kalkışması halinde, kendilerinin de Anadolu'ya asker çıkaracakları tehdidinde bulunmuşlardır. Türkiye, Musul sorununun ikili görüşmelerle çözümlenmesini masaya yeni istekler sürerek, beklenmedik şekilde engelleyen İngiliz politikasının, gelecekte ne gibi süprizler hazırlamakta olduğunu tahmine çalışırken, İngiltere Irak'ta arzularına uygun gelişmeleri yönlendirmektedir..$^{92}$ Ingiltere Irak Meclisi'ne manda süresini belirleyen kararı kabul ettirmiştir.

Haliç Konferansı'nın dağılmasından bir süre sonra İngiltere, Ankara'ya konuyu Milletler Cemiyeti'ne birlikte götürme önerisinde bulunmuştur.Türk Hükümeti bu girişim üzerine 4 A ğustos 1924 günü, İngiltere'ye yeni bir ikili görüşme yapmaları önerisinde bulunmuş, bu girişime İngiltere 6 Ağustos günü tek başına Milletler Cemiyeti'ne müracaat etmek suretiyle cevap vermiștir. ${ }^{93}$

7 Ağustos günü Nesturiler, Hakkari Valisi'ni pusuya düşürüp esir alarak, Nesturi ayaklanmasını başlatmışlardır. Musul meselesinin Milletler Cemiyeti'ne götürüldügüü günlerde, ihtilaflı sınır bölgesinde Türkiye'ye karşı bir Hıristiyan azınlık ayaklanması, Milletler Cemiyeti'nin İngiliz görüşlerini çok daha dikkatli ele almasına yol açabilirdi. Bu nedenle Nesturi ayaklanmas1, Musul konusunda İngilizlerin lehinde bir gelişme olmuştur. ${ }^{94}$

Milletler Cemiyeti'nin 11 Ağustos tarihli davetine, 25 Ağustos günü cevap veren İsmet Paşa, Türk temsilcisinin gönderilebilmesi için yirmi gün

\footnotetext{
92 Uluğbay, a.g.e., s.246.

${ }^{93}$ Cumhuriyetin İlk On Y 11, s.86.

${ }^{94}$ Uluğbay, a.g.e., s.248.
} 
süre verilmesi talebinde bulunmuştur. Türkiye bu isteğinin kabul edilmesinden sonra hazırlıklarını tamamlamış ve 20 Eylül tarihinde Türkiye'yi temsilen Fethi (Okyar) Bey görüşmelerde hazır bulunmuştur. Milletler Cemiyeti Konseyi'nin 30 Eylül 1924 tarihli oturumunda TürkiyeIrak sınırı konusu ele alınmış ve bu konuda konseyin bir değerlendirme yapabilecek bilgileri derlemesi için,üç üyeli özel bir komisyon kurulmasına karar verilmiştir. ${ }^{95} 13$ Kasım 1924'te Cenevre'de bir araya gelerek çalışmalarına başlayan komisyon üyeleri, Lozan Barış Görüşmeleri tutanaklarını, Türk ve İngiliz Hükümetleri'nin Milletler Cemiyeti Genel Sekreterliği'ne verdikleri raporları inceledikten sonra, 25 Kasım 1924 günü Londra'da İngiliz makamları ile görüşmelere başlamış, buradaki çalışmalarını tamamladıktan sonra 3 Ocak 1925 'de Ankara'ya hareket etmiştir. Komisyon Ankara'daki temaslarını bitirdikten sonra 16 Ocak 1925 günü Bağdat'a gelmiștir. Bağdat'ta ve tartışmalı bölgelerde çalıșmalarını sürdüren komisyon, 16 Temmuz günü hazırladığı raporu Milletler Cemiyeti Genel Sekreterliği'ne sunmuştur.

Milletler Cemiyeti'nin çalışmaları devam ederken, Musul vilayetinde Türk ve İngiliz birlikleri arasında yer yer çatışmalar sürmektedir. İngiltere 9 Ekim 1924'te Türk Hükümeti'ne bir ültimatom vererek, Türk askerlerinin 48 saat içinde İngilizler tarafından kabul edilen sınır hattının gerisine çekilmesini, aksi taktirde zor kullanacağını bildirmiștir. ${ }^{96}$ Bunun üzerine Türk Hükümeti, geçici bir sınır tesbiti için Milletler Cemiyeti Meclisi'ne başvurmuştur. Türkiye'nin bu talebi üzerine 29 Ekim 1924 günü Brüksel'de olağanüstü bir toplantı yapan Milletler Cemiyeti Meclisi, Türkiye ile Irak arasında geçici bir sınır belirlemiş ve tarafların "Bruxelles Sınırı"şeklinde nitelenen sınıra uymalarını istemiştir. Nesturi ayaklanmasının bastırılmasından ve İngilizlerin sınır anlaşmazlığı yaratmalarından sonra 23 Ekim 1924'de Genel Kurmay Başkanı Mareşal Fevzi Paşa, Milli Savunma Bakanlığı'na bir rapor sunarak, "Musul konusunda belirsizliğin sürdüğünü, Ingilizler'in bir yandan çeşitli durumlar yaratarak, siyasi görüşmeler hazırlayarak zaman kazanmaya çalıştıklarını, bir yandan da Irak'ta daha güclü olmak hususuna önem verdiklerini kaydederek, bu ortamda Türkiye'nin, Musul vilayetinin kuzeyinde sıkı yönetim ilan etmesinin ve izinli subaylart süratle Irak kıtalarına göndermesinin" ${ }^{97}$ gerekliliğini vurgulamıştır. Bölgede yaşanan gelişmeler nedeniyle Kuzey Irak'ta sıkı yönetim ilan edilmesine ihtiyaç hisseden Fevzi Paşa'nın, kaygılarında haklı olduğu çok geçmeden görülecektir. 13 Şubat 1925 günü Şeyh Sait, yanındaki üçyüz kadar atlı kuvveti ile birlikte Piran'da bir vaaz vermiştir. Şeyh Sait bu vaazında özellikle şu konuları vurgulamıştır.

95 Uluğbay, a.g.e., s.250.; Komisyon üyeliklerine eski Macaristan Başbakanı, İsveç'in Bükreş Büyükelçisi ve Belçikalı bir emekli albay atanmışlardır.

${ }^{96}$ Mehmet Gönlübol-Cem Sar, Olaylarla Türk Dış Politikası (1919-1973), Ankara, 1982, C.I., 5. Baskı, s.75,

${ }^{97}$ Uluğbay, a.g.e., s. 251 
“...Medreseler kapandl, Şer'iyye ve Evkaf Bakanlıkları kaldırıldı. Tüm okullar Maarif Teşkilatı'na bağlandı. Gazetelerde bir takım dinsiz yazarlar dine hakaret etmeye, Peygamberimize dil uzatmaya cür'et ediyorlar.Ben bugün elimden gelse bizzat dövüssmeye başlar, dinin yükselmesine yardım ederdim...98

Aynı gün, altı asker kaçağının izini sürerek, Piran köyüne gelen Jandarma birliğine, Şeyh Sait'in kaldığı evden ateş açılması ve onu izleyen günlerde yaşanan olaylarla birlikte Şeyh Sait ayaklanması patlak vermiştir. Bu gelişme İngilizlerin eline Musul konusunda beklenmedik bir firsat vermiştir. Musul'da görevli bir İngiliz, Halifeliğin kaldırıldığı haberine inanamamıştır. Sözü edilen bu İngiliz görevli yakalanan bu fırsatı şu sözlerle ifade etmiştir:

“Kürdistan'l patlamaya hazır bir volkan gibi kaynatan Türk propagandası, Kürtlerin Halife'ye kesin bağlılıklarına dayanıyordu. Türkler'in bindikleri dalı kesmeleri ise, Ingiltere için inanllmayacak kadar mükemmel bir şey olmuştur... Tabii, bu durumdan kendimiz (Ingiltere) için yararlanmayt ihmal etmedik".

Irak ve Londra'daki İngiliz yönetimi Türkiye'deki reform hareketlerini kendi çıkarları için kullanma gayreti içerisinde iken, Fransa'nın Bağdat'taki Yüksek Komiseri de Paris'e gönderdiği raporunda, “...Ayaklanmacılara silahlar İtalya'dan gelecekti. Kürt hareketi Berlin'de Cumhuriyet karşıtı Türkler, Misırlı ve Hintli eylemciler tarafindan desteklendi" demektedir. ${ }^{99}$ Bu bilgiler İngiltere ve İtalya'nın, Şeyh Sait ve adamları tarafından çıkarılan ayaklanmadan haberdar olduklarını göstermektedir. İngilizler belki de bu ayaklanma ile bir anlamda Türkler'den, Milli Mücadele'de uğradıkları yenilginin intikamını alacaklardır. Nitekim Şeyh Sait ayaklanması Türklerin Musul üzerindeki iddialarını araştıran, Milletler Cemiyeti'nin oluşturduğu komisyon üzerinde de Türkiye aleyhinde etki yapacak, Türkiye daha kendi toprakları üzerinde yaşayan Kürtler arasında bile huzuru sağlayamamıştır, gibi bir izlenim yaratacaktır. Gerçi, Şeyh Sait ve adamlarının sorguları sırasında, bu olayda özellikle İngilizlerin katkısı olduğu gerçeği görülecektir. Ancak bu durum, İngilizlerin bu olayı Musul meselesinde kullanarak, Musul'u Türkiye'ye vermeme yolunda çok önemli bir avantaj elde etmeleri gerçeğini de değiştirmeyecektir.

Türkiye'nin Şeyh Sait ayaklanmasını bastırıp, Şeyh Sait ve adamlarını İstiklal Mahkemeleri'nde yargıladığı, inkılâp karşıtı güçlere karşı Takrir-i Sükun Kanunu'nu uygulamaya koyduğu günlerde, Milletler Cemiyeti Komisyonu'nun raporu tamamlanmıştır. Komisyonun hazırladığı doksan sayfalık raporun sonuç bölümünde şöyle denilmektedir:

\footnotetext{
${ }^{98}$ Uluğbay, a.g.e., s.252.

${ }^{99}$ Kürkçüoğlu, a.g.e., s.309-310.
} 
"Komisyon yasal açıdan bakıldı̆̆ında sorunlu bölgenin, bu konudaki hakkını reddedinceye kadar, Türkiye'nin ayrılmaz bir parçası olduğu görüsündedir. Konuya sadece ilgili nüfusun çıkarları açısından bakıldı̆̆ında, komisyon sorunlu bölgenin taraflar arasında paylaşımının sakıncalar yaratacağı görüşündedir. Bu dü̈sünceden hareketle komisyon, belirlemiş olduğu gerçeklere gerekli önemi atfederek ve özellikle ekonomik, coğrafi ve bölgede yaşayanların çoğunluğunun eğilimleri gibi önemli unsurları da göz önünde bulundurarak, Bruxelles Stnırı'nın güneyindeki tüm toprakların, Irak'a uygulanacak mandaterlik süresinin 25 yıl olmast ve Irak yönetimine girecek Kürtler'e bazı haklar tanınması şartıyla, Irak'a bırakılması görüşünü benimsemiştir". ${ }^{100}$

Komisyon görüldüğü üzere, sorunlu toprakların yasal açıdan Türkiye'nin ayrılmaz bir parçası olduğunu kabul etmiş, ancak bölge halkının çıkarlarını gerekçe göstererek, Musul'un Irak'a, daha doğrusu İngiliz çıkarlarının emrine verilmesine karar vermiştir.Bu rapor üzerine Türk Hükümeti, 23 Temmuz 1925 günü Milletler Cemiyeti’ne başvurarak,şu hususlara dikkat çekmiştir:

1-Komisyon sorunlu bölgede çalışmalarını sürdürürken, yöredeki Arap yöneticiler, Türkiye'nin tezlerini zayıflatıcı yönde faaliyet göstermişlerdir.

2-Komisyonun yaptığı mülakatlarda, Türk yanlısı görüş bildirenler yerel yönetim tarafından rahatsız edilmiş, korkutulmuş, hatta hapse atılmakla tehdit edilmişlerdir.

3-Komisyon Musul'dan ayrıldıktan sonra, yöre halkına geniş çapta yaptırım uygulanmıştır.

4-Irak yönetimi, Türkiye lehinde olan ve Dohuk-İmadiye çizgisinde yerleşik aşiretleri bombalamıştır.

5-Bu baskılardan kaçan bazı aşiretler, Türkiye'ye sığınmak zorunda kalmışlardır. ${ }^{101}$

Londra Ankara'nın bu suçlamalarına, Irak Hava Kuvvetleri'nin gösteri uçuşları yaptığı şeklinde cevap vermiş, diğer iddiaları ise, asayişe yönelik önlemler olarak nitelemiştir. İki ülke arasında devam eden karşılıklı suçlamalar, İngiltere tarafından Milletler Cemiyeti zeminine çekilmiş, Cemiyet'ten Hrristiyanlara yapılan baskıları yerinde incelemek üzere yöreye bir heyet gönderilmesi talep edilmiştir.

$\mathrm{Bu}$ gerginliklerin yaşandığı günlerde Milletler Cemiyeti Konseyi, Musul meselesini görüşmeye başlamıştır. 3 ve 4 Eylül oturumlarında Türkiye ve İngiltere birbirleri hakkındaki iddialarını tekrarlamışlardır. Bu çerçevede Tevfik Rüştü Bey, İngiltere'yi Doğu Akdeniz donanmasını göndererek, askeri tehditte bulunmakla ve sınır ihlalleri ile suçlamış, İngiliz Temsilcisi ise, bu suçlamayı reddederek, sınır ihlallerinden Türkiye'yi sorumlu

\footnotetext{
${ }^{100}$ Uluğbay, a.g.e., s. 255 .

${ }^{101}$ Uluğbay, a.g.e., s.256.
} 
tutmuştur. Komisyonda üzerinde tartışmaların en çok yoğunlaştı̆̆ konu ise, Milletler Cemiyeti'nin komisyon raporu üzerinde alacağı kararın, bağlayıcı bir niteliğinin olup olmayacağı meselesidir. Türkiye, Konsey'in sadece kendi antlaşması ile belirlenmiş esaslar çerçevesinde karar verebileceğini, Musul meselesinin, Cemiyet Antlaşması'nın 15. maddesi çerçevesinde incelenmesini savunmuştur. Tartı̧̧malar 19 ve 24 tarihli oturumlarda da yoğunlaşınca, Konsey iki ara karar almak zorunda kalmıştır. ${ }^{102}$ Bunlardan birincisi, Milletlerarası Daimi Adalet Divanı'ndan, Lozan Antlaşması'nın 3/2' ye göre, Konsey'in kararının niteliği konusunda görüş bildirmesidir. İkincisi ise, sınır sorunu konusunu yerinde incelemek üzere, tartışmalı bölgeye bir heyet göndermeye karar vermesidir. Bu sorunlardan ilki çerçevesinde Komisyon, Divan'a şu iki soruyu yöneltmiştir:

1-Lozan Antlaşması'nın 3/2 kararı uyarınca, Konsey tarafından alınacak kararın niteliği nedir?

2-Karar, oybirliği ile mi, yoksa oy çokluğu ile mi alınmalıdır. Konu ile ilgili olarak taraflar oylamaya katılacaklar mıdır?

İngiltere bu süreç içinde batı basınını Türkiye aleyhinde harekete geçirme konusunda oldukça başarılı olmuştur. Basında Türkiye'nin sorunlu bölgelerde yaşayan Hıristiyanlara kötü davrandığı konusunda geniş haberler yer almıştır. Bu da doğal olarak batı kamuoyunu, dolayısıyla da Konsey üyelerini Türkiye aleyhinde düşünmeye itecek bir gelişmedir.

Milletler Cemiyeti Konseyi, Adalet Divanı'ndan beklediği cevabı 21 Kasım 1925 günü almış, Divan sorulara şu cevapları vermiştir:

1-Lozan Antlaşması'nın 3/2 fıkrası uyarınca, Milletler Cemiyeti Konseyi'nin alacağı karar tarafları bağlayıcıdır ve Türkiye ile Irak arasındaki kesin sinır olacaktır.

2-Karar oybirliği ile alınmalıdır. Tarafların temsilcileri oylamaya katılabilir, ancak onların oyları oybirliğini belirlemede göz önüne alınmamalıdır. ${ }^{103}$

Adalet Divanı'nın raporundan iki gün sonra, tartışmalı bölgeye gönderilen heyetin raporu da Komisyon'a ulaşmıştır. Bu raporda da "Hıristiyanların göçe zorlanmasının, Bruxelles Stnırı'nın güneyinde yașayan Hiristiyan ve Müslüman nüfus arasında huzursuzluk ve heyecan yarattığl, Ankara'nın sinırdaki statükoyu bozmak amacıyla zaman zaman sinırın güneyine sarktı̆̆ı" değerlendirmeleri yapılmıştır.

Milletler Cemiyeti Konseyi'nin Musul konusundaki karar günü yaklaşırken, İngiltere'de karara karşı Türkiye'nin olası tavrını kestirmeye ve strateji belirlemeye başlamıştır. Bu amaçla İngiliz Dışişleri Bakanı Chamberlain, 4 Aralık 1925 günü Türk Büyükelçisi Ahmet Ferit Bey’le görüşmüş ve "Türkiye'nin Milletler Cemiyeti'nce alınacak karar karşısında,

\footnotetext{
${ }^{102}$ Uluğbay, a.g.e., s.256.

${ }^{103}$ Uluğbay, a.g.e., s.257.
} 
bu milletlerarası kuruluşu hiçe sayacak bir davranışa girmeyeceğini ümid ettiklerini ifade etmiş, aksi bir durumla karşılaşmaları halinde, Türkiye'nin karşısında Büyük Britanya Imparatorluğu'nu bulacă̆ının bilinmesini” istemiştir. Ayrıca "Kararın Türkiye aleyhinde çıkması halinde, aralarında görüşerek Türkiye tarafından daha kabul edilebilir imkanları araştıracaklarını" da söylemiştir. ${ }^{104}$ İngilizler görüldüğü üzere her şekilde kararın kendi lehlerinde çıkacağı beklentisi içindedirler.

Milletler Cemiyeti Konseyi İngilizleri yanıltmamış, 16 Aralık 1925 günü Musul konusundaki kararını açıklamıştır. Bu karara göre:

1-Bruxelles Sınırı Türkiye ile Irak arasında sınır olarak belirlenmiştir.

2-İngiltere, Irak'la yeni bir antlaşma imzalayarak, Irak'taki mandaterlik süresinin bitiminden önce, Milletler Cemiyeti Antlaşması'nın 1. maddesi uyarınca, Cemiyet'e üye kabul edilmedikçe yürürlükte kalmak üzere mandaterlik süresini 25 yıl daha uzatarak, sonucunu Konsey'e sunmaya davet edilmiştir. ${ }^{105}$

Konseyin bu kararı Türk kamuoyunda sert tepkilere yol açmıștır. 17 Aralık 1925 tarihli “Cumhuriyet”, Türkiye Musul'u süngü ile almaya mecbur edilmektedir, demiş̧; diğer günlük gazetelerde de savaşın yakın olduğuna dair haberlere yer verilmiştir.Ancak basındaki savaş çığırtkanlığına karşın, ülke yeni bir savaşı kaldıracak durumda değildir. Şeyh Sait ayaklanmasının yarattığı sıkıntılı ortam sürerken, Doğu Anadolu'da bir de "Sason ayaklanması" patlak vermiştir. Ülke reformları halka kabul ettirebilme mücadelesi vermektedir. Kalkınmaya, sanayileşmeye ihtiyaç vardır. Yeni bir savaş bütün bu işlerin yapılabilmesini geciktirecektir.Bunun için Atatürk ve arkadaşlarının öfke ile değil de, sükunetle ve akılla hareket etmeleri gereklidir. Nitekim Tevfik Rüştü Bey, İngiliz Büyükelçisi Lindsay ile yaptığı görüşmede, mevcut durumun kabul edilebileceği izlenimini vermiş, taraflar arasında Irak sınırına yönelik ilk kapsamlı görüşme 21 Nisan 1926 günü Tevfik Rüştü Bey ile Lindsay arasında gerçekleştirilmiştir.Tevfik Rüştü Bey'in taleplerini Lindsay, Londra'ya şu şekilde sunmuştur:

1-Türkiye, Sovyet Rusya ile olduğu gibi, İngiltere ile de karşılıklı bir tarafsızlık antlaşmasının imzalanmasından yanadır.

2-Türkiye, Bruxelles Sınırı'nın güneyinde kalan toprakların üçlü bir antlaşma ile kendi kendini tam yönetebilen bir Irak Devleti'ne birakılmasından yanadır.

3-Tevfik Rüștü Bey, Türkiye'ye Irak petrollerinden pay verilmesinden yanadır. ${ }^{106}$

\footnotetext{
${ }^{104}$ Kürkçüoğlu, a.g.e., s. 315 .

${ }^{105}$ Uluğbay, a.g.e., s. 259.

${ }^{106}$ Kürkçüoğlu, a.g.e., s.315-316.
} 
İngiliz Büyükelçisi Lindsay, 23 Nisan 1926 günü Londra’ya gönderdiği telgrafında, Türkiye'nin bu istekleri üzerinde bazı önerilerde bulunduktan sonra, petrol konusunda Türkiye'ye bir ödün verilmediği taktirde, yeniden Türkiye'nin toprak talepleri ile karşılaşabilecekleri konusunda uyarıda bulunmuştur. ${ }^{107}$

İngiltere ise, Türkiye'ye ile uzlaşmanın gerekliliğini kabullenmekle birlikte, İtalyan tehdidinin devam ettiğini, Mussolini'nin Türkiye'ye güvence vermesi durumunda, Ankara'nın yeniden İngiltere ile sertleşme yoluna gidebileceği endişesini taşımaktadır. ${ }^{08}$

Lindsay ile Türk Hükümeti yetkilileri arasında süren görüşmeler kısa sürede olgunlaşmıs, Lindsay Londra'ya gelişmeleri şöyle izah etmiştir:

"Türkiye mali açıdan çok sıkıșık durumda olduğundan, bu ïlkeye toprak tavizi vermek yerine, tarafımdan 500.000 sterlin karşılıksız ödeme önerilmiştir. Dışişleri Bakanı, Hükümet'e danıştıktan sonra bu meblağın çok yetersiz olduğunu bildirmiştir. Bakan, ülkesinin 1909 yılında BosnaHersek'in, Avusturya-Macaristan Imparatorluğu'na birakılması karşılığında almış olduğu tazminattan ${ }^{109}$, daha düşük bir miktarl kabul edemeyeceklerini bildirmiş ve Türk tarafı karşı teklif olarak, Osmanlı borçlarından T.C'nin payına düşen miktar kesinleştikten sonra, bu borcun ilk üç yıllık faizini Ingiltere ve Irak'ın birlikte ödemelerini, ayrıca Türkiye'ye karşılıksız olarak 1 milyon sterlin ödenmesini talep etmiştir". İngiliz bürokrasisi bu bilgileri, ilgili tüm birimlerine duyurmuştur.Türkiye ile yapılan ikili temaslardan günü gününe haberdar olan Bağdat'taki İngiliz Yüksek Komiseri, Lindsay'in önerilerini desteklemiştir. Yüksek Komiser'in uyarıları üzerine Sömürgeler Bakanlığı, 24 Mayıs günü Dışişleri Bakanlı̆̆ı'na Türkiye'nin 500.000 sterlini yeterli bulmaması halinde, Büyükelçi Lindsay'e 1 milyon sterline kadar önerme yetkisi verilmesini talep etmiştir. Bir gün önce de Lindsay, Ankara'dan İngiltere'ye gönderdiği mesajda, kendisine 775.000 sterline kadar öneri götürme yetkisi verilmesini istemiştir. Büyükelçi Lindsay’in bu talebi İngiliz Hükümeti tarafından olumlu karşılanmıştır. ${ }^{110}$

Müzakereler sonucunda sınırda Türkiye lehine küçük bazı değişiklikler yapılması ve Irak Devleti'nin petrolden alacağı "Royalty"nin \%10'unu yirmibeş yıl süreyle Türkiye'ye ödemesi esası üzerinden anlaşmaya varılmıştır. Sonuçta, 5 Haziran 1926 tarihinde Ankara'da Türkiye ile İngiltere ve Irak Hükümetleri arasında Türk-Irak Sınırı ve İyi Komşuluk İlişkileri Antlaşması imzalanmıştır. Antlaşmanın, Türkiye'nin Musul petrollerinden alacağı hisseye ilişkin 14. maddesi incelendiğinde,

\footnotetext{
${ }^{107}$ Kürkçüoğlu, a.g.e., s.316.

${ }^{108}$ Kürkçüoğlu, a.g.e., s.317.

${ }^{109}$ Osmanlı Devleti'nin Bosna-Hersek'ten vazgeçmesi karşılığında aldığı tazminat miktarı 2.2 milyon sterlindir.

${ }^{110}$ Kürkçüoğlu, a.g.e., s.318.
} 
Türkiye'nin alacağı \%10'ların hesabına; Türk Petrol Şirketi'nin kendisinden, ortaklarının ve yan ortaklarının Irak'taki faaliyetlerinden, Irak Devleti'nce alınan tüm "Royalty"ler dahildir. ${ }^{11}$ Ek mektupta ise, Türkiye'ye bir seçme hakkı tanınmıştır. Türkiye antlaşmanın yürürlüğe girmesini izleyen bir yıl içinde, isterse "Royalty" ler yerine topluca 500.000 sterlin alabilecektir.

Şimdiye kadar yazılmış olan tüm siyasi tarih kitaplarında Türkiye'nin 500.000 sterlin seçeneğini kullanarak, \%10'luk "Royalty" hakkından vazgeçtiği bilgisi yer almaktadır. ${ }^{112}$

Uluğbay’a göre, 1934 yılından itibaren Bütçe Kanunları ve Kesin Hesap Kanunları incelendiğinde, 1934-1958 döneminde yirmidört yılın Bütçe Kanunları "B" cetveline ve 1959-1985 döneminde de Bütçe Kanunu maddeleri içine Musul petrolleri için gelir tahmini konulmuş ve onsekiz yılın Kesin Hesap Kanunlarında da "Sözleşmesi Gereğince Musul Petrollerinden Alınan" başlığı altında, bu gelirlerin tahsil edilmiş olarak gösterildiği görülür. T.C.Hükümeti'nin 500.000 sterlin seçeneğini kabul edip, "Royalty" hakkından vazgeçtiğine ilişkin hiçbir kaydın mevcut olmadığını kaydeden Uluğbay'a göre, Musul petrolleri için "Royalty" hakkının onsekiz yıl süre ile Irak Hükümeti'nden alındığı belirlenmiştir. Uluğbay'ın çalışmalarının sonucuna göre, Türkiye'nin Irak petrollerinden alması gereken pay yaklaşık 5.5 milyon sterlindir. Bu alacak karşılığında kesin hesaplara geçen miktar Uluğbay'a göre 25.7 milyon TL.dir. Bu miktarda o günün değeri ile 3.5 milyon sterlin etmektedir. Dolayısıyla ilk kez bu bilgileri ortaya koyan Hikmet Uluğbay'ın görüşüne göre, Türkiye'ye 5 Haziran 1926 tarihli antlaşmada öngörülen 25 yıllık "Royalty" gelirinden, yaklaşık 2 milyon sterlin eksik ödeme yapılmıştır.

\footnotetext{
${ }^{111}$ Uluğbay, a.g.e., s.261.

${ }^{112}$ Baskın Oran, Türk Dış Politikası'nda şöyle demektedir: A.B.D. dünyaya aldırmadan Irak'a saldırmaya hazırlanırken, medyada bir firtına esiyor. Irak'ın bize petrol parası borcu var. Milyarlarca dolar, tam sırasıdır. Hemen isteyelim. Medya bu bilgiyi yeni öğrendi.Bu borç, 5 Haziran 1926 tarihli Türkiye-İngiltere-Irak Antlaşması'nın 14. maddesinden kaynaklanmakta. Buna göre Irak, 25 yıl süreyle, kendi petrol gelirinin \%10'unu Türkiye'ye ödeyecek. Aynı gün İngiltere ile Irak, Türkiye'ye verdikleri ortak bir notada, eğer Türkiye isterse, Irak'ın bu hesabı bir defada 500.000 sterlin vererek kapatacağını söylüyorlar. Her ne hikmetse, biz Mülkiye'de okurken bu seçeneğin kabul edildiğini bize öğrettiler ve maalesef aynı hatayı yıllar boyu bu sefer biz öğrettik. Bütün Türkiye'de böyle öğrendi. Sonunda Kasım 2001'de Türk Dış Politikası kitabını yazarken, Uluğbay'ın kitabından öğrendik ki, Türkiye toplu para seçeneğini değil, \%10'u kabul etmiş. $\mathrm{O}$ gün bugündür işin doğrusu öğrenildi...Irak bu \%10'ları hemen ödemeye başlıyor ve bu paralar 25 yılın tamamlandığı 1951'e kadar, Bütçe Kesin Hesap Kanunu'nda “ Sözleşmesi gereğince Musul petrollerinden alınan” başlığı altında gözüküyor. 1952 ve 1953 yıllarında ödeme yok. 1954'de herhalde bizimkiler Irak'1 geriye bakiye borç kaldı diye uyarıyorlar ki, yüklüce bir ödeme var. 1955 yılında yine ödeme yok ve bu yıl bu kalem bütçede "gelir tahmini" olarak gözüküyor. Bundan sonra hiç yok. Ta, 1959'a kadar. 1959'da bu kalem "alacak" başlığı altında yine geri geliyor ve 1986'ya kadar böyle devam ediyor. Bu tarihten sonra tamamen kalkıyor. Bir daha geri gelmemek üzere. Baskın Oran, "Agos" gazetesi, 10.1.2003.
} 
1951 yılına kadar düzenli ödenen “Royalty”ler, Uluğbay’a göre, Menderes döneminde, Irakla oluşturulan dostluk ilişkileri nedeniyle Irak Hükümeti'nden talep edilmemiştir.1958'de Irak'ta General Kasım'ın bir darbe ile iktidarı ele geçirmesi ve Türkiye-Irak ilişkilerinin gerginleşmesinden sonra, bu paranın tahsil edilebilmesi mümkün olamamıștır. Türkiye Özal döneminde ise bu biriken meblağdan hukuken vazgeçmiştir. ${ }^{113}$

\section{SONUÇ}

Musul çok zor bir coğrafyadır ve Misak-1 Milli sınırları içerisindedir. Musul Meselesi'nin çıkışından itibaren Mustafa Kemal Paşa, Musul'un Misak-ı Milli sınırlarına kazandırılması doğrultusunda çaba göstermiş, çeşitli demeçlerinde Musul'un anavatanın ayrılmaz bir parçası olduğunu tekrarlamıştır. Hatta Lozan Görüşmeleri'nin çıkmaza girmesi üzerine Musul'u savaşarak almak görüşü ağır basmış, Kazım Karabekir Paşa'ya Musul'un geri alınması için teklifte bulunulmuş, ${ }^{114}$ ancak gerek Şeyh Sait isyanı nedeniyle, gerekse İtalya ve Fransa'nın bu savaşta İngiltere ile birlikte hareket edeceği tehlikesi nedeniyle bu düşüncenin hayata geçirilebilmesi mümkün olamamıştır.

Musul meselesi nedeniyle Türkiye'nin karşı karşıya kaldığı ülke İngiltere ise, o dönemde dünyanın en güçlü devletidir. Ekonomik alanda çok güçlü olan İngiltere'nin, siyasi alanda da çok güçlü olmasına karşın, Türkiye hem ekonomik açıdan fakir, hem de buna paralel olarak siyasi açıdan da güçsüz ve yalnızdır. İngiltere görüşmelerde son derece hazırlıklı, Türkiye ise, İngiltere kadar hazırlıklı değildir.

Musul'un kaybedilmesine yönelik gelişmeler zinciri, Türklerin henüz petrolün önemini kavrayamamış olduğu günlerde, Musul'da güçlü petrol kaynaklarının varlığının ortaya çıkarılması ile başlamıştır. Petrol alanları

\footnotetext{
${ }^{113}$ Uluğbay, a.g.e., s.262.

${ }^{114}$ Kazım Karabekir Paşa bu teklife pek sıcak bakmamıştır.Kazım Karabekir Paşa Musul yüzünden girişilecek bir savaşın sakıncalarını, İsmet Paşa'ya şu sözlerle aktarmıştır:" Bu hareket İngilizlere karşı ilansız bir harp demek olur.Oradaki kıtaları az da olsa, tayyare kuvvetleri üstündür. Kısa bir zamanda takviye edebilirler. Sevk olunacak kuvvetlerimizin orada dahi muvaffakiyetlerini ümit etmem.Fakat işin tehlikeli ciheti, bu hareketin İngilizlerin bütün sahillerimizde faaliyete geçmelerine mucip olur. İşin daha felaketli ciheti de, Ermeni ve Yunan ordularıyla yapamadığını, bu sefer Suriye'den Fransızlar'la ve İzmir'den de İtalyan ordularıyla yapmaya kalkışmasıdır. İzmir Harp Oyunu'nda İtalyanların böyle bir hareketi misal olarak yaptırıldığı halde, şimdi onun fiilen tatbikini görmek istiyorsunuz. Yunanistan bile derhal Şarki Trakya'yı işgale can atacaktır. Bu suretle tarihi utançlarından kurtulmak isteyeceklerdir.Nitekim İzmir Harp Oyunu'nda bu hareket de hesaba katılmıştı. Bundan başka dünya kamuoyunda Türklerin her fırsatta harbe atıldıkları şekli göstereceğinden, siyasi ve askeri düzenimiz ve neticede Musul uğruna kazandığımız istiklalimiz de tehlikeye düşer" Kazım Karabekir Anlatıyor, Yayına Hazırlayan: Uğur Mumcu, Tekin Yayınevi,18. Basım, s.137.
} 
üzerinde hakimiyet kurabilme mücadelesi yüzünden Almanya ile İtilaf Devletleri arasında Basra Körfezi'nde yaşanan gerginlik, I. Dünya Savaşı'na yol açan önemli bir gelişmedir. Musul'un kaybedilmesini kolaylaştıran ikinci önemli halka ise, Osmanlı Devleti'nin I.Dünya Savaşı'ndan sonra Ali İhsan Paşa'ya direniş göstermeden Musul'u boşaltması talimatını vermiș olmasıdır. Milli Mücadele yıllarında zaten imkansızlıklar yüzünden Musul konusunda bir şey yapılabilmesi mümkün değildir. Dolayısıyla Türkiye Wilson Prensipleri'nin, milletlere kendi geleceklerini tayin etme hakkı veren kararına güvenerek, Lozan'a Musul'un Türkiye'ye bırakılacağından emin olarak gitmiştir. Türkiye İngiltere'den farklı olarak, Musul meselesini bir toprak meselesi olarak görmüş, gerekirse petrolden taviz vererek, Musul'u elde etme mücadelesi vermiştir. Şevket Süreyya Aydemir'in ifadesiyle, "Türk insanına bu vatan için ölmek öğretilmiş, ancak ayakta kalanların bu ülkeyi şahlandırmak için nasıl bir ekonomik akıl geliştirecekleri gerçeği öğretilmemiştir". ${ }^{115}$ İngiltere ise, bu ekonomik aklın bilincindedir. Bu nedenle Lozan'da petrol konusundaki isteklerini Türklerden çok iyi gizlemeyi başaran İngilizler, Lozan'daki en önemli başarıyı, müttefik devletlerin de ilgilerini bu konuya çekerek, Musul meselesini çok taraflı hale getirerek elde etmişlerdir. İngilizlerin Lozan'daki ikinci önemli başarısı ise, çok taraflı hale getirdikleri bu sorunun çözümünü, Milletler Cemiyeti'ne havale etme kararını Türkiye'ye kabul ettirebilmeleridir. Türkiye Milletler Cemiyeti'ne üye değilken, İngiltere bu örgütün en etkili üyesidir. Sevres Antlaşması'nı kabul etmeyerek, bir Kurtuluş Savaşı veren, İngiltere ve Fransa'nın planlarını bozan Türkiye'ye, bu ülkelerin petrol açısından ve stratejik açıdan önemli olan Musul'u vermelerini beklemek boşunadır. Yani, Musul'un geleceği Lozan'da şekillenmiştir. Lozan'dan sonraki ikili görüşmeler, oynanan oyunun uzatma dakikalarıdır. İkili görüşmelerden sonra Musul meselesinin Milletler Cemiyeti'ne havalesi ile, İngilizler amaçlarına ulaşmışlardır. Dolayısıyla, uluslararası alandaki yalnızlı̆̆ı, Türkiye'ye Musul konusunda zarar vermiştir. Bu da Türkiye'yi Ankara Antlaşması'nı imzalayıp, Musul meselesini sonuçlandırma, ülkeyi Sovyet Rusya'nın tekelinden kurtararak, bir an önce batı dünyası ile uzun süredir düzene sokamadığı ilişkilerini düzenleme mecburiyetine itmiştir. Ancak yeni ortaya atılan bilgilerin 1şı̆̆ı altında görülmektedir ki, ortada Musul konusunda bizim öğrendiklerimizle çelişen bir durum mevcuttur. Türkiye, siyasi tarih kitaplarında yer aldığı şekliyle, 500.000 sterlin alarak Musul üzerindeki tüm haklarından vazgeçmesi yolunu seçmemiş, 25 yıl süreyle Irak petrollerinden $\% 10$ pay alma seçeneğini tercih etmiştir. Ancak 25 yıllık petrol gelirine karşılık Türkiye'ye on sekiz yıl düzenli ödeme yapılmış, Irak Hükümeti tarafından ödenmesi gereken meblağdan yaklaşık 2 milyon sterlin eksik ödeme yapılmıştır. Yani Türkiye Musul'u kaybettiği gibi, Musul Meselesi'ni ekonomik açıdan pek de karlı olarak değerlendiremeyeceğimiz bir şekilde noktalamıştır.

${ }^{115}$ Şevket Süreyya Aydemir, Menderes'in Dramı (1899-1960), Remzi Kitabevi, 7. Basım, 1999 , s.65. 